تجارب دانشجومعلمان از نقش مربى در بيوند نظر و عمل در برنامه كارورزى

\title{
Teacher Training Students' Experiences of the Role of Coach in Linking Theory and Practice in Practicum
}

\section{A. Jamshidi Tavana (Ph. D), M. Imam Jomae (Ph. D), A. Assare (Ph. D)}

\begin{abstract}
:
Future teachers are current teacher-students who focus on developing teachers' knowledge in the field of theory and practice in practicum as an important part of the teacher-training program. One of the effective factors in the pre-service programs is school coach that has been studied in this research. The research method used here was qualitative method through phenomenology research. Among 22 cases, focus was on 3 participants. Participants are students of 91-92 university year who have completed 3 practica. The data was collected through semi-structured interviews and participants' observation. Also, semi-structured interviews were done with their mentors. Data were categorized by using Strauss and Corbin analysis procedure. The findings show that coach as the most effective factor in this profession can develop teacherstudents' competences. A coach do this effective task through these roles: imitation, joint-experience, and rethinking.
\end{abstract}

Keywords: Coach, Teacher training, teacher student, practice, practicum

$$
\begin{aligned}
& \text { دكتر اعظم جمشيدى توانا '، دكتر محمدرضا }
\end{aligned}
$$

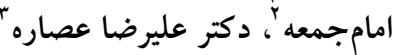

$$
\begin{aligned}
& \text { جكيده:معلمان آينده، دانشجومعلمان كنونى هستند كهي }
\end{aligned}
$$

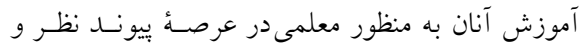

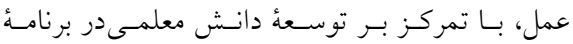

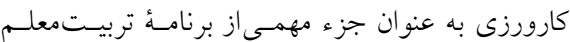

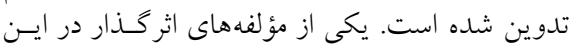

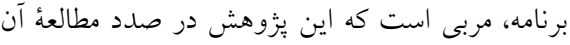

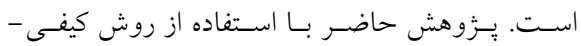

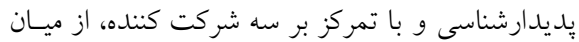

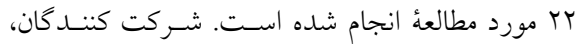

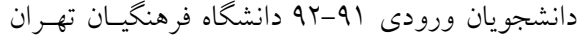

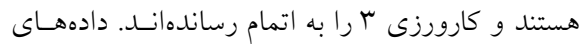

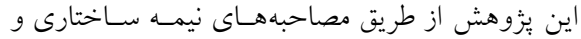

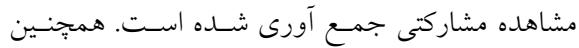

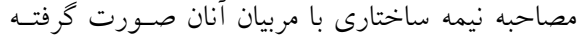

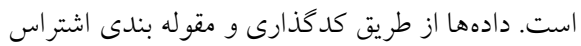

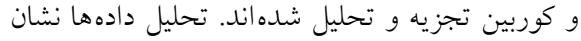

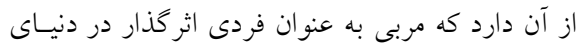

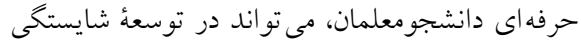

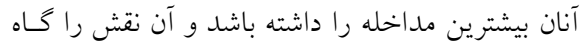

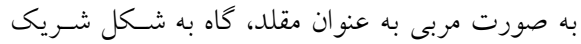

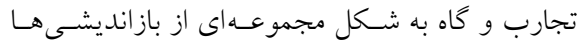

$$
\begin{aligned}
& \text { نشان ميدهد. }
\end{aligned}
$$

وازگًان كليدى: مربسى، تربيـت معلــــم، دانشـجومعلم،

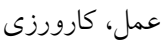

$$
\text { 'ادانش آموحته دكترى و مدرس علومتربيتى دانشگاه شهيدرجائى (نويسنده مسئول) }
$$

رايانامه: azam4365jamshidi@gmail.com

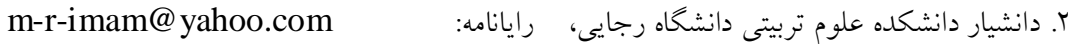

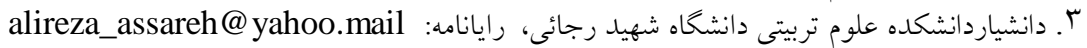


دو فصلنامة نظريه و عمل در برنامئ درسى، شماره V، سال جهارم، بهار و تابستان 9011

\section{مقلمهه}

كارورزى جزء ارزشمندى از برنامهُ تربيتمعلم است. دانشجومعلمان در طى كارورزى، با دانش و مهارتهاى شغل معلمى آشنا مىشوند و وظايفى از حرفه معلمى را تجربه مى كنند. آنجهه بيش از هر جِيز اهميت دارد، بررسى نظريه ها و اتخاذ رويكرد مطلوب براى اصلاح و بهسازى كارورزى در تربيت معلم مىباشد. يكى از نظرات در حرفه آموزى، الخوى مهارتى 'است؛ در اين الخو، دانش حرفهاى در يك كارورز حرفهاى با تهن تجربه وجود دارد. او در عمل حرفهاى خويش متخصص است. كارآموز به وسيلة تقليد فن از متخصص و بييروى از آموزش ها و رهنمودهاى او حرفه را ياد مى گيرد، طى اين فرايند، تبحر حرفهاى از نسلى به نسل ديخر منتقل خواهد شد. استاد به شاكردانش

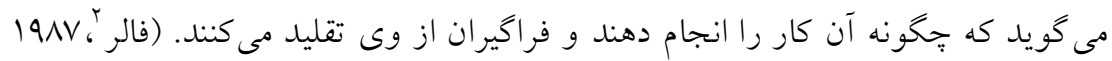

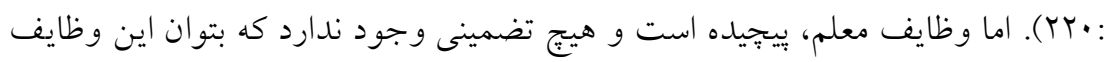
را كاملاً بيش بينى نمود. اين الكو به مسائلى كه در موقعيت هاى گوناگون، معلمان با آن مواجه مىشوند، توجهى ندارد. علاوه بر آن عيب ديخر روش فوق در اين است كه "(معلم آينده، فقط يك تقليد كننده بار مى آيد، جرا كه او فقط آنجه را كه مىبيند، انجام

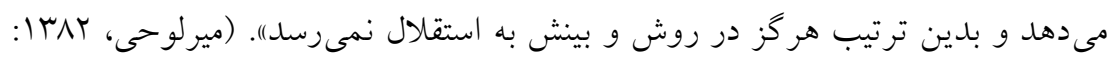

(TOD

الكوى علم كاربردى مدلى سنتى و شايد هنوز رايجترين الخويى است كه بسيارى از برنامههاى تربيت حرفهاى خواه يزشكى، معمارى، معلمى و يا هر شغل ديخر بر پايئ آن قرار دارد. قدرت اين الكو از بيشرفت علوم تجربى، به خصوص در قرون نوزده و بيست، سرجشمه مى گيرد. در اين جارجوب، دانش عملى دربارة هر جيزى، به طور

\section{${ }^{1}$-Craft Model}

2 - Fuller

${ }^{3}$-Applied science modle 
ساده، ((مطلبى است درباره مناسبترين وسيلهها براى دستيابى به اهداف تعيين شدها).

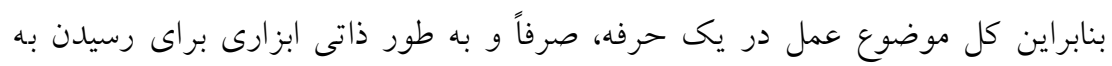

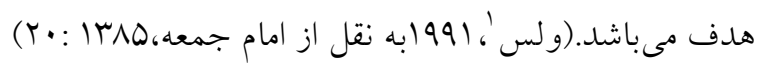

با به كاركيرى تحقيقات تجربى در حوزههاى گوناگون، رويكردهاى غير علمى به

تربيت معلم نفى مى گردد به طورى كه مسائل تدريس، كلاس درس و مدرسه را مىتوان به وسيلة به كارگيرى علوم تجربى در جهت نيل به اهداف مورد نظر حل كرد.

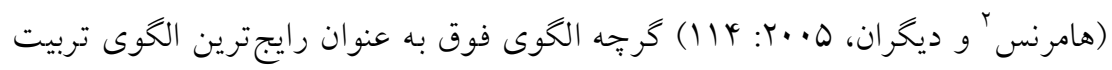
حرفهاى يذيرفته شده است؛ اما در طى دهههاى اخير، شك فزايندهاى در مورد سودمندى اين الخو در بين صاحب نظران مطرح شده است. نقطه مركزى اين انتقادات مربوط به شكافى است كه در اين الخو بين نظريه و عمل وجود دارد. همجنين در اين الكو، تحقيقات علمىو دانشخاهى، دانش حرفهاى مفيدى را نتيجه مى دهل و تدريس اين دانش در مدارس، فراگيران را براى عمل در جهان واقعى آماده مى سازد و اين آموزش ها مىتواند آنها را براى حل مسائل جهان واقعى مهيا سازد. در الخوى علم كاربردى، يافتهاى دانش علمى به وسيله كسانى كه متخصص هستند به فراكيران منتقل مى شود. وظيفه فراخيران به عنوان كارگزار اين است كه نتيجههاى حاصل شده از اين يافتههاى علمى را در عمل بياده نمايند و اخر در اين عمل شكست بخورند، احتمالاً بدين علت است كه آنها به طور مناسبى يافتهاى علمىرا درى نكردهاند و يا به گونه مناسبى اين يافته را به كار نخرفتهاند، دانش علمى وقتى حرفهاى مى شود كه براساس تحقيقات علمىباشد. (شون، 199 :•r|) در اين الكو كارورزان به عنوان ابزارهاى حل كننده مسأله، بهترين وسايل تكنيكى حاصل از مطالعات علمى را براى اهداف خاص انتخاب مى كنند. كارورزان حرفهاى كه در كار خود دقيق و سخت

\footnotetext{
${ }^{1}$-Wallace

2 -Hammerness
} 
كير هستند، مسائلى را كه از قبل جارجوب بندى شده و خوب شكل كرفته، با به كارگيرى نظريه و تكنيكهاى سر جشمه كرفته از دانش علمى منظم حل مى كنّلد.

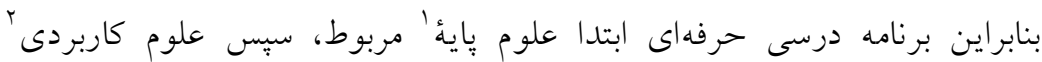

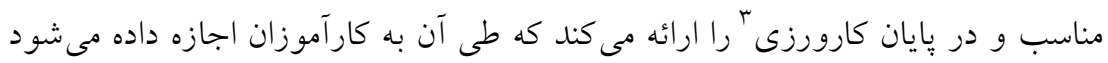
تا ياد بخيرند كه جِكونه دانش مبتنى بر تحقيقات را براى حل مشكلات كارى عمل روزانه خويش به كار برند، اين نخاه سلسله مراتبى به دانش، جدايى بين دنياى

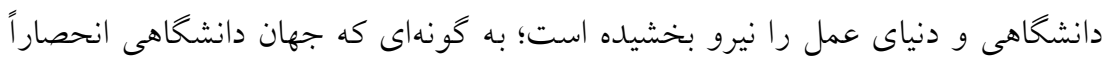

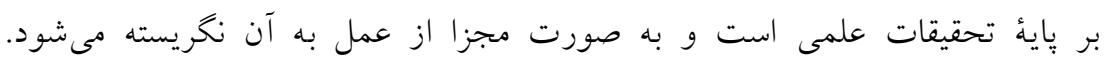

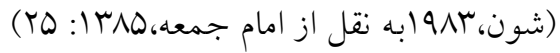

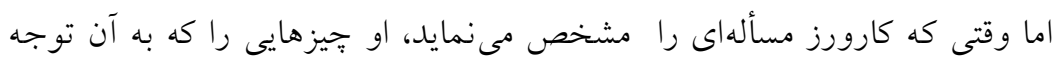

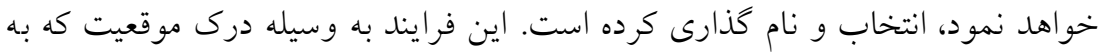

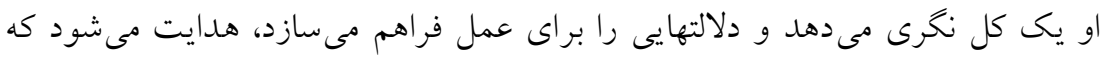

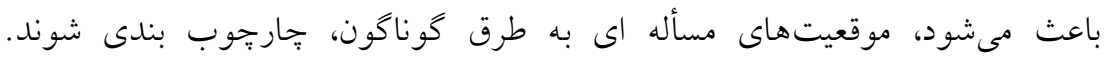

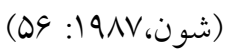

به نظر زوزف شواب؛، براى صورتبندى كردن مسأله به هنگام رويارويى با يكى

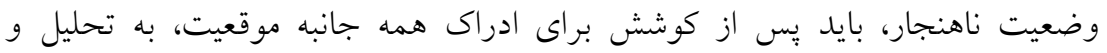

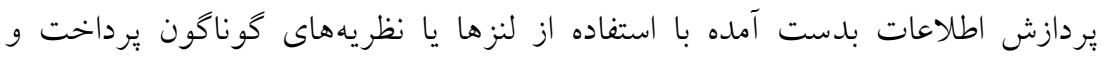

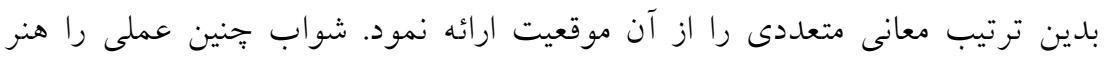

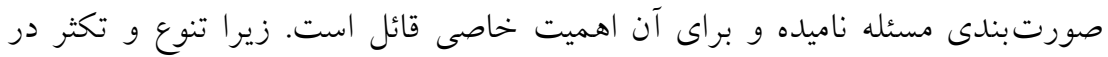

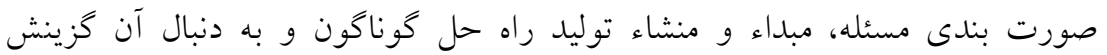

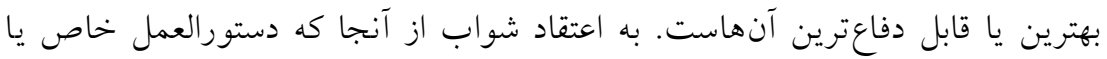

\footnotetext{
${ }^{1}$-Basic Science

${ }^{2}$-Applied Science

${ }^{3}$-Practicum

4-Schwab
} 
الكوريتمى براى اين فرايند وجود ندارد، بايد راهيابانه' عمل كرد. وى تاكيد مى كند كه

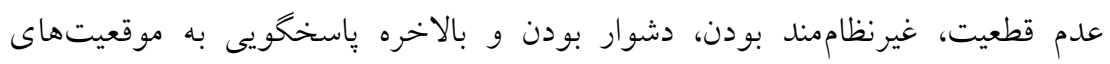

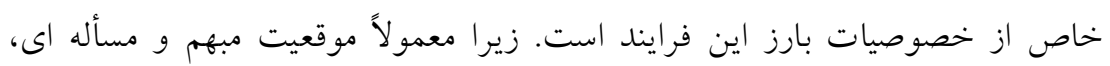

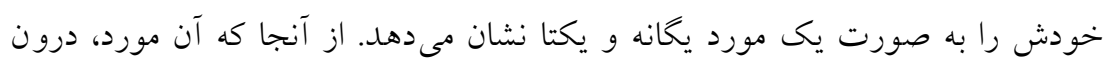

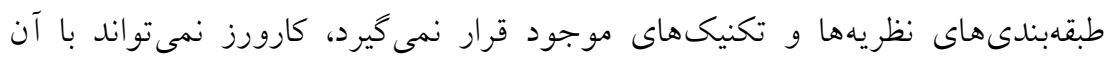

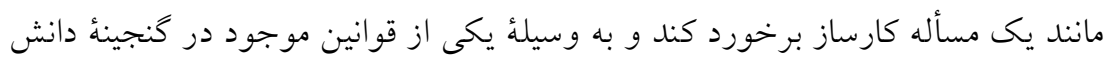

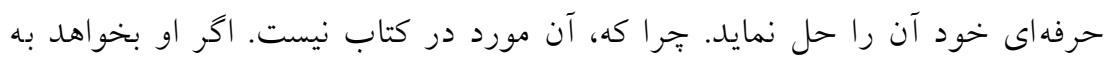

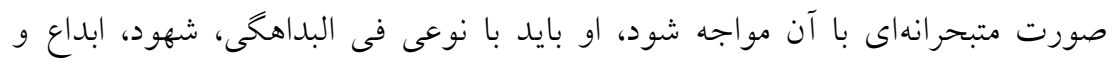

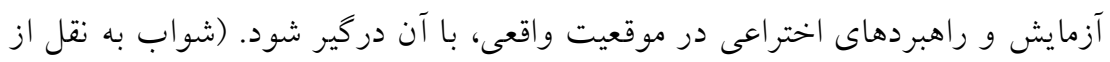

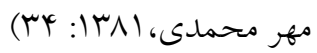

در اين موقعيتها، اهداف واضح و ثابتى وجود ندارد تا كارورز به انتخاب تكنيكى

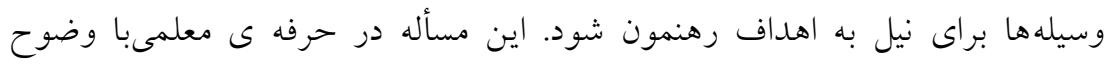

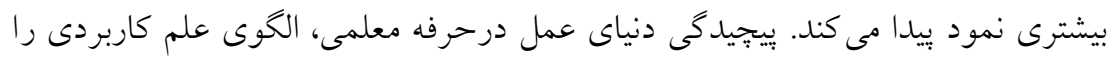

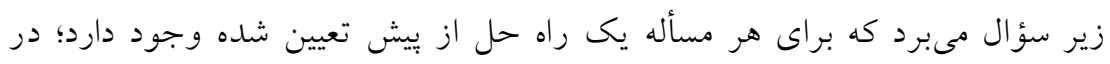

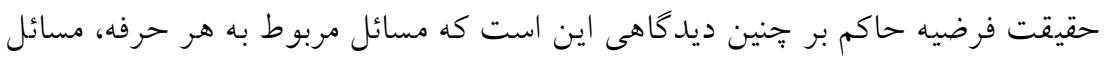

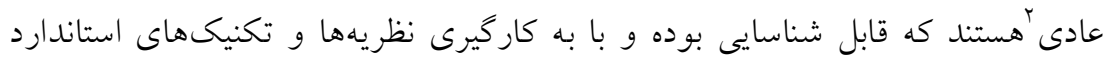

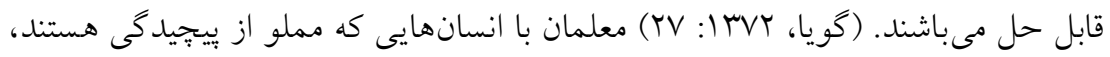

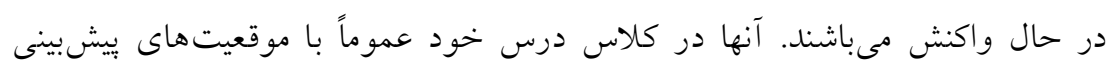

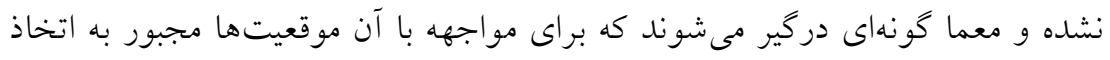
تصميم هايى هستند.

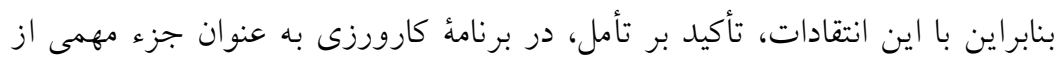

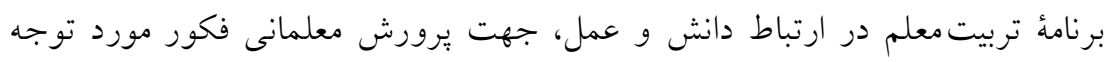

\footnotetext{
${ }^{1}$-Heuristic

${ }^{2}$-Routine
} 
است. مفهوم تأمل توسط دو محقق برجسته، جان ديويى وُ دونالد شون بيان شده است،

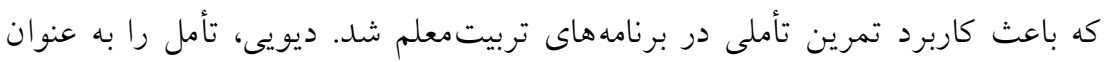

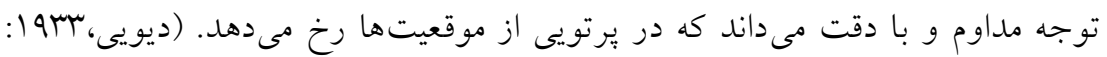

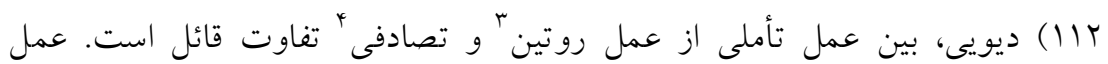

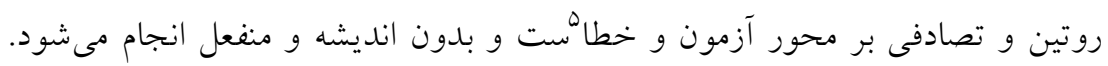

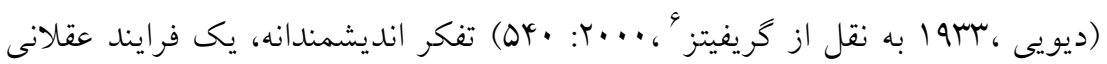

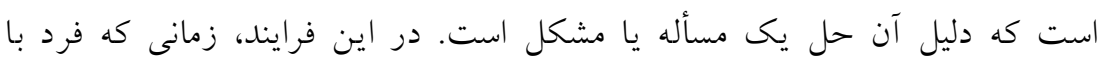

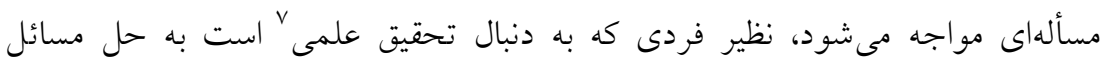

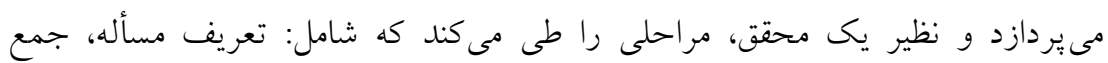

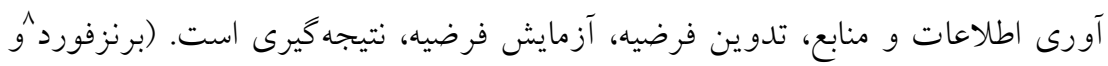

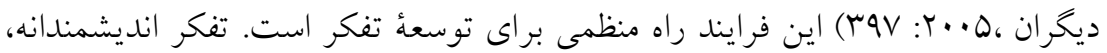

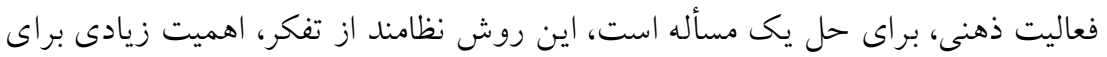
توسعهُ تربيتمعلم جهت يرورش معلمان فكور و اثر بخش دارد، در صورتى كه همراه با تجزيه وتحليل انتقادى و مسوليت در مقابل عمل انجام شده است. (كورتاجن؛ (TTO:199T

شون، تفكر را به عنوان مركزى براى دانش حرفهاى مىداند و تأمل حين عمل "

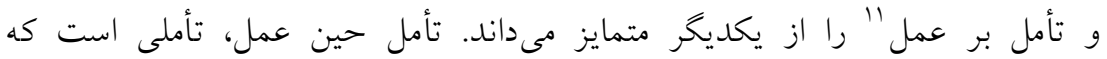

1 - John Dewey

2 -Donald Schön

3 - routine

${ }_{5}^{4}$-impulsive

5 - trial and error

${ }^{6}$-Griffiths

${ }^{7}$-scientific inquiry

8 -Bransford

9 - Korthagen

${ }^{10}$ - reflection in action

${ }^{11}$-reflection on action 
دانشجومعلمان زمانى كه با موقعيت مسألهاى در كلاس درس مواجه مىشوند؛ به منظور

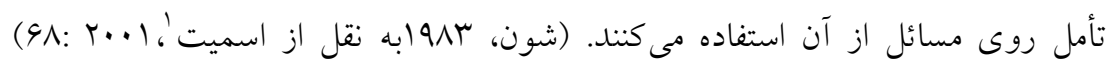

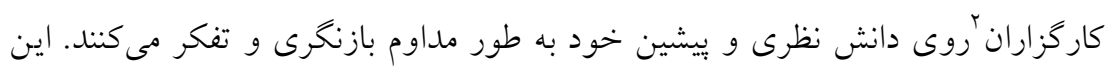

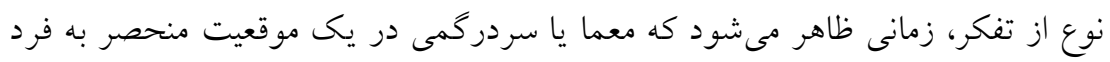

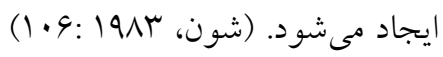

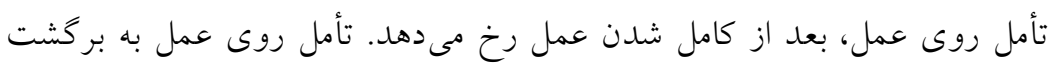

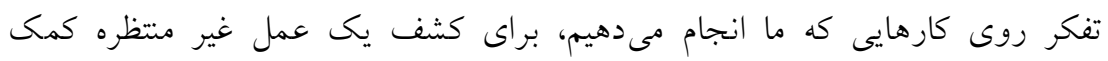

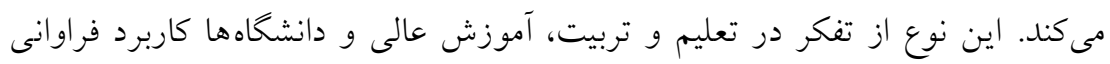

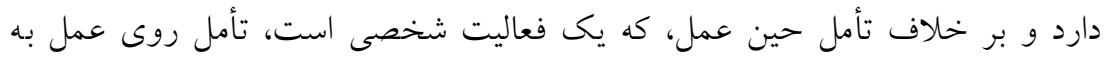

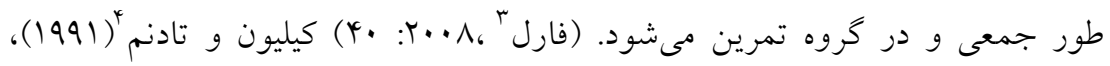

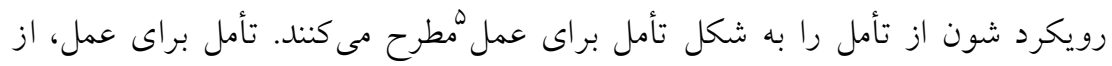

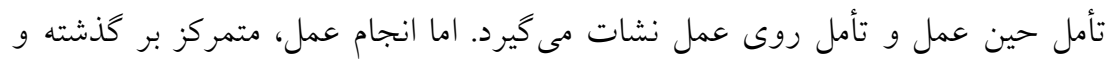

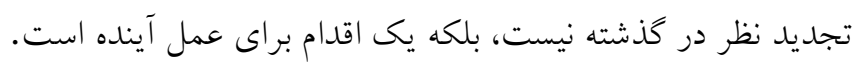

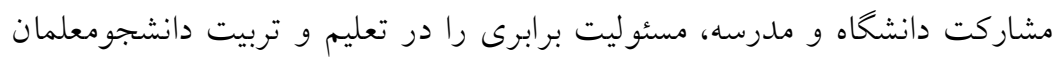

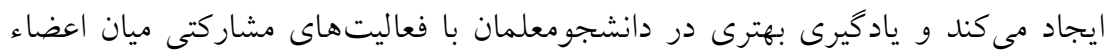

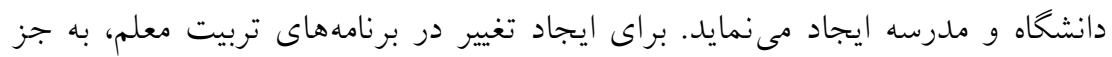

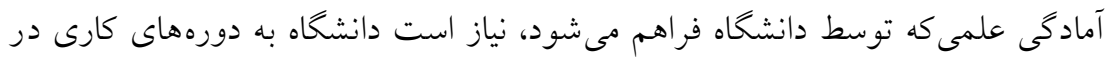

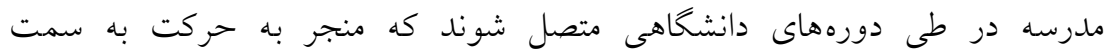

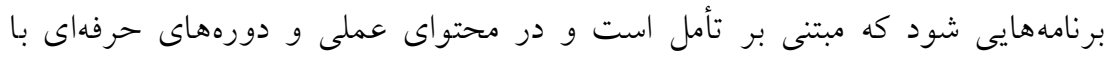

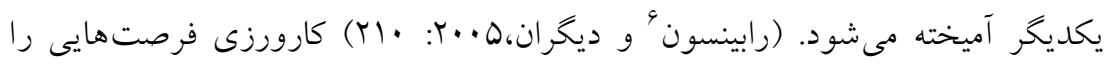

\footnotetext{
1 - Smith

2 -practitioner

${ }^{3}$-Farrell

${ }^{4}$-Killion \& Todnem

5 - reflection for action

${ }^{6}$-Robinson
} 
همراه با نظارت و كمك به دانشجومعلمان براى فهم گسترده از نقش كارگزاران فكور

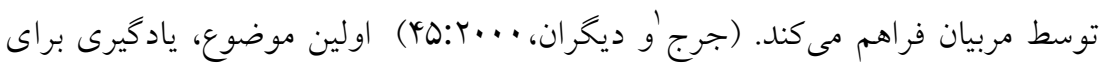

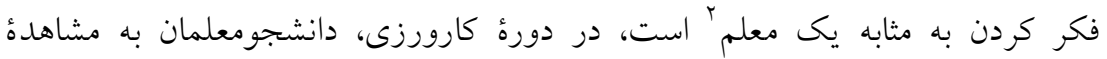
موقعيتهاى كلاس درس، مدرسه و تدريس مى يردازند و باورهاى قابل توجهى از معلمى را در درون خود شكل مىدهند و تصوراتى از اين حرفه را به عنوان معلمان

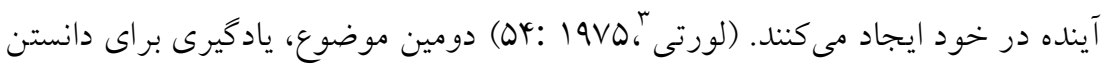

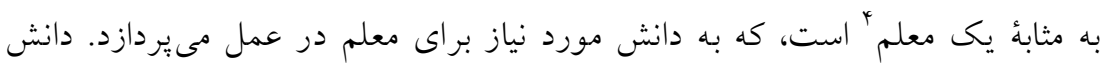

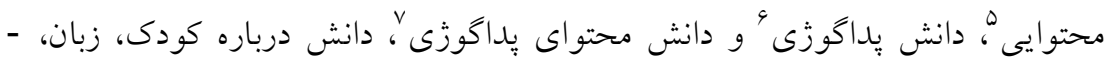

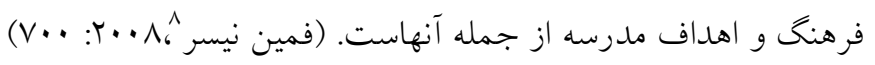

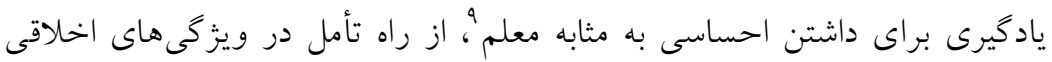

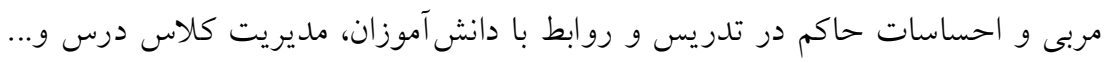

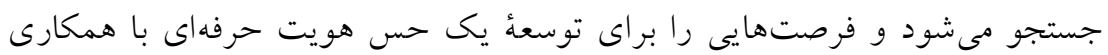

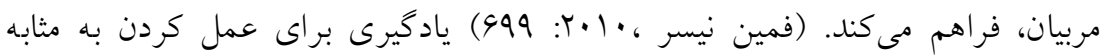

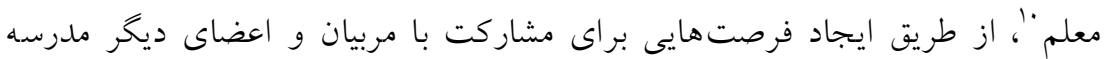

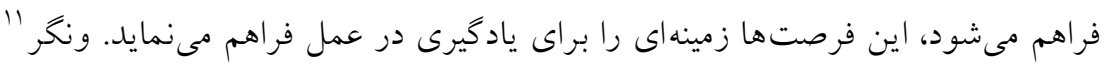

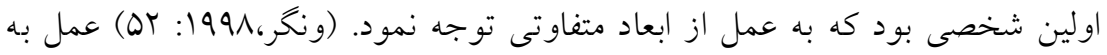

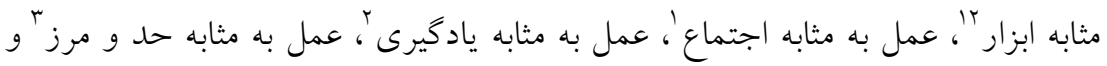

\footnotetext{
1 - George

${ }^{2}$ - learning to think like a teacher

3 - Lortie

4 - learning to know like a teacher

5 -content knowleg

6 -padagogy knowlege

${ }^{7}$-pedagogical content knowlege

${ }^{8}$-Feiman Nemser

9 - learning to feel like a teacher

${ }^{10}$ - learning to act like a teacher

11 - Wenger

12 - practice as meaing
} 
و عمل به مثابه موقعيت'، معانى را در ارتباط دانش با عمل از راه تحقيق مشخص مىنمايد، كه هر يك زيرمجموعهاى از اعمال را در برنامه كارورزى در برمى كيرد. عمل ببه مثابه ابزار، دانشجومعلمان را كمك مىنمايد تا با دقت اعمال ديخران را مشاهده كنند و ياد گيرىهاى خود را در موقعيت هاى هدفمند به كار كيرند. دو فرايند "مشاركت "ه "عينيت" " اساسى براى عمل به مثابه ابزار است. مشاركت، يكى فرايند فعال است كه در مدرسه با همكارى مربيان كسب مىشود، اما هيج تلاشى از جانب دانشجومعلم براى ارتباط با مربى و يا ساير همكاران در مدرسه صورت نمى گيرد. عينيت، درى از عمل، با مشخص ساختن استاندارهاى مربوط به آن، در طراحى دروس، مديريت محيط يادكيرى و ارزشيابى از دانش آموزان است كه بيشتر بر مديريت كلاس درس و دانش محتوايى رشته در دانشجومعلمان تمركز دارد. اين عمل بر عادتها و مهارت هاى مشخصى در عمل تأكيد دارد.

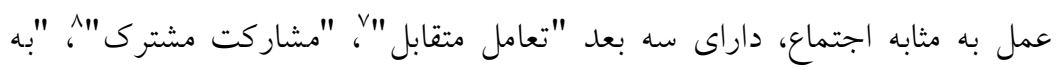
اشتراى كذاشتن كزارشات" است. با به اشتراك گذاشتن گزارشهايى از مدرسه و كالس درس دربارة مسائل، راهحل هايى براى برخورد و حل مسائل از راه تعامل فراهم

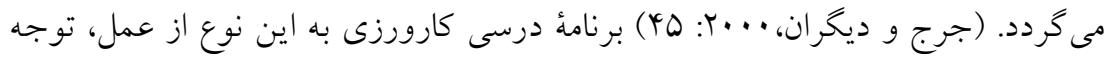
عميقى داشته و بر ارتباط متقابل، مشاركت مشترك و به اشتراك گذاشتن گزارشات ميان مربيان در مدارس و استادان راهنما در دانشخاه و همكالسى ها تأكيد دارد.

1 - practice as community

2 - practice as learning

3 - practice as boundary

4 - practice as locality

5 - participation

6 - reification

7 - mutual engagement

8 - joint enterprise

9 - shared repertoire 
عمل به مثابه يادگيرى، عمل به مثابه ابزار و عمل به مثابه اجتماع را در بر مى گيرد و

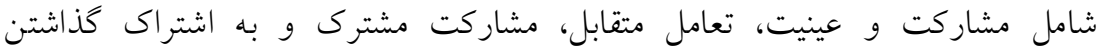

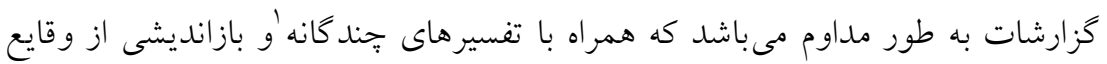
و مسائل است. مشاركت در مسائل باعث مىشود دانشجو معلمان قبل از اينكه با باليا آزمايش - خطا به نتايجى در تدريس دست يابند، با مشاركت به نتايجى فراتر برسند.

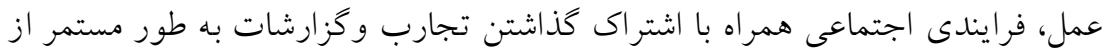

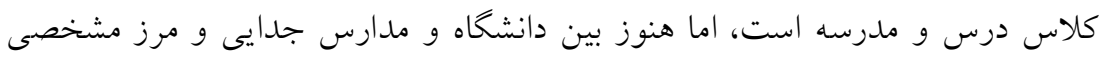

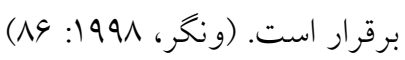
در عمل به مثابه حدود، بين جوامع عمل (دانشخاه و مدرسه) تعامل برقرار مى شود.

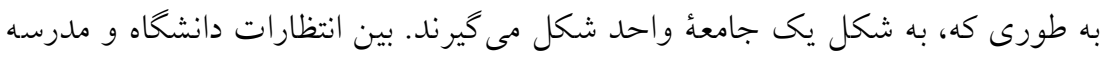
هيج گونه جدايى نمى توان ديد و ارتباط نزديكى ميان دانشجومعلمان، مربيان و استادان

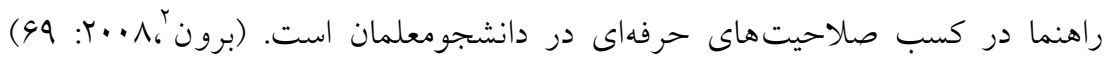

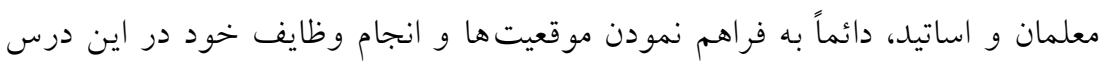

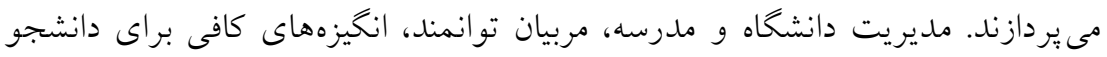
معلمان در شكل گيرى عمل حرفهاى فراهم مى كند.

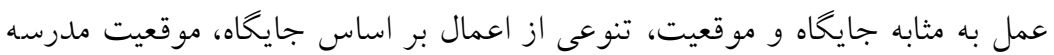

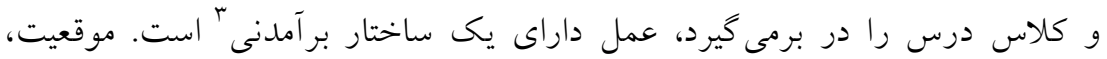

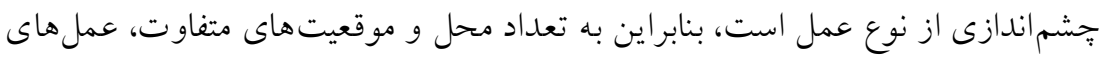

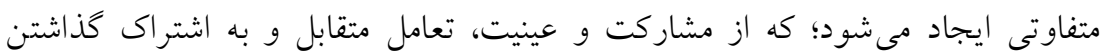

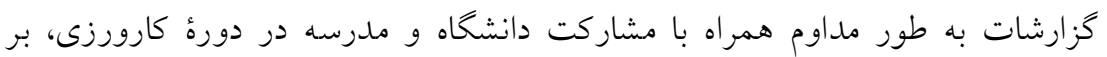

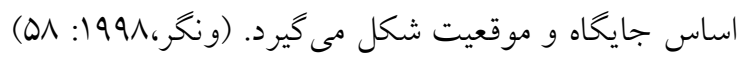

\footnotetext{
1 - multiple interpretation

2 -Brown

3 - emerge
} 
بنابراين مىتوان كفت كه عمل دانشجومعلمان در دورهُ كارورزى با هميارى مربيان

$$
\begin{aligned}
& \text { در مدارس، داراى ويزگى هاى ذيل است: }
\end{aligned}
$$

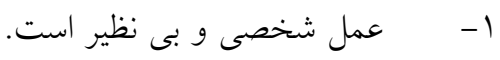

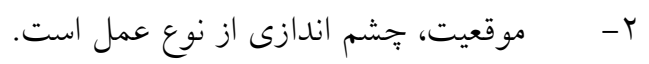

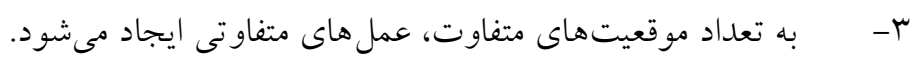

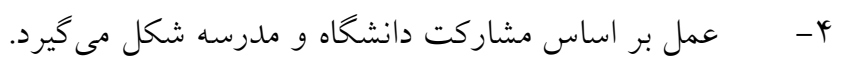

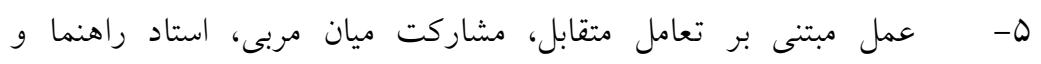

$$
\begin{aligned}
& \text { همكلاسى ها به طور مستمر است. }
\end{aligned}
$$

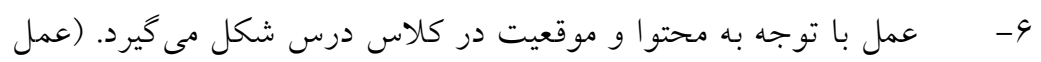

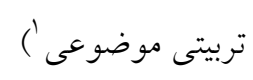

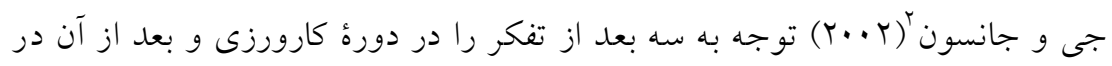

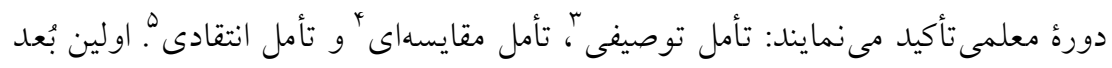

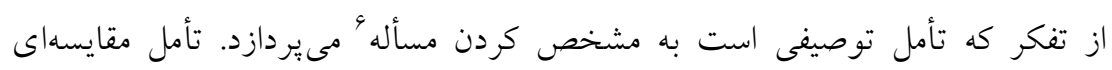

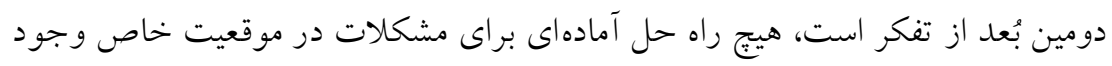

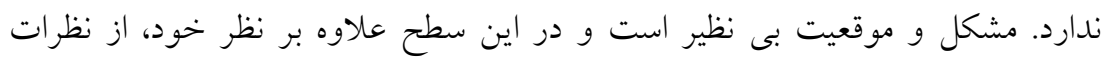

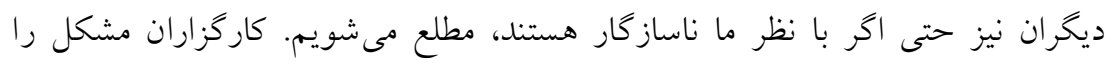

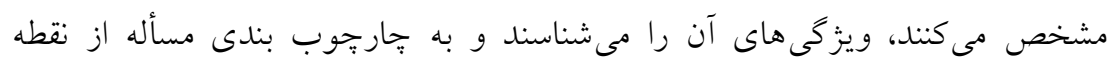

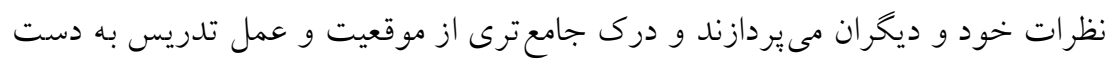

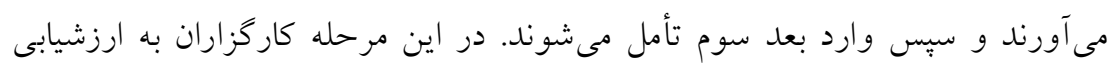

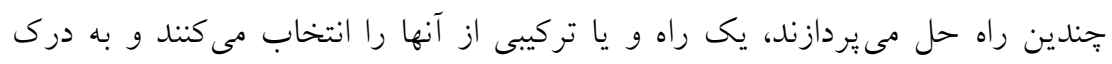

\footnotetext{
${ }^{1}$-pedagogical content knowlege

2 - Jay \&Johnson

3 -descriptive reflection

${ }^{4}$-comparative reflection

5 - critical reflection

${ }^{6}$ - problem-setting
} 
بهتر و جديدى از مسأله مى يردازند. شون (ب/911) بيان مى كند، كاركزاران در اين مرحله

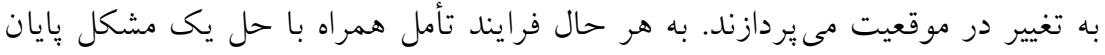

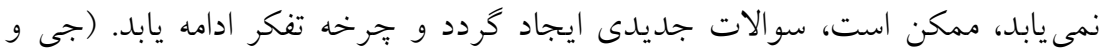

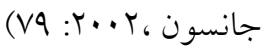
بنابراين تأمل يك فرايند ذهنى مستمر وُ بازانديشى در حين عمل و بعد از عمل است كه نتايجى در رفتار دارد، يس اساسى براى تغيير و توسعهُ دانش حرفهاى معلم

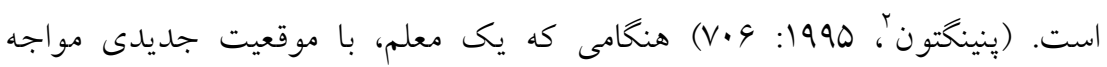

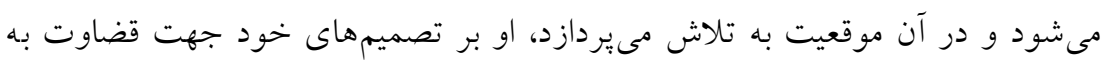
فرايند تأمل مى يردازد. كاربرد مهارتهاى تأمل و تفكر در مراحل كارورزى، تغييراتى را براى دانشجو

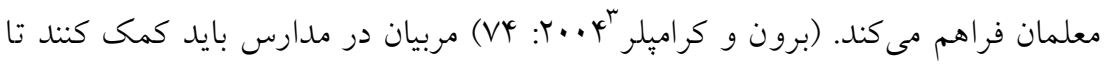

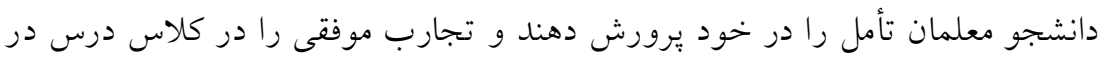

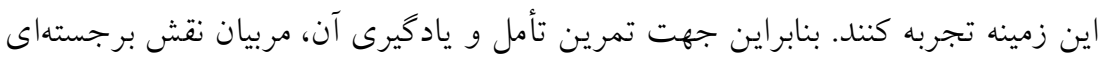
در ميان مجر يان برنامئ درسى كارورزى دارند.

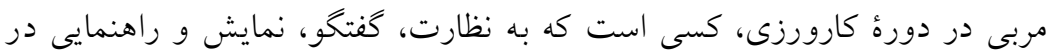

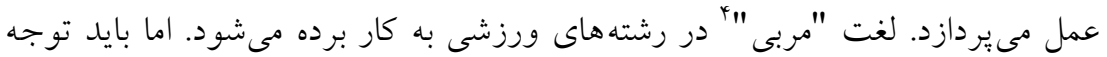

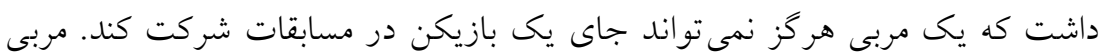

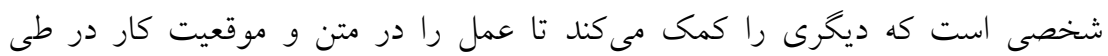

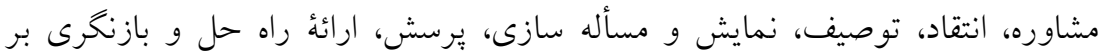

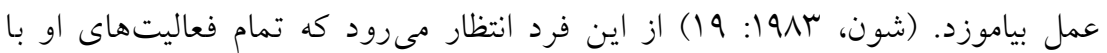
مربى گرى همر اه شود.

\footnotetext{
- on-going

2 -Pennington

${ }^{3}$-Braun \& Crumpler

${ }^{4}$-coach
} 
دانشجو معلم از طرح درس، عمل تدريس و يادگيرى دانشآموزان، مديريت

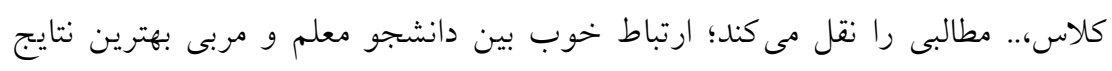

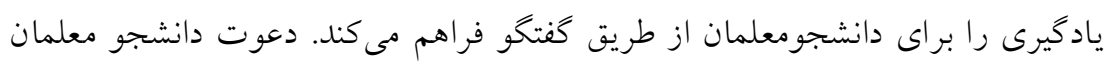

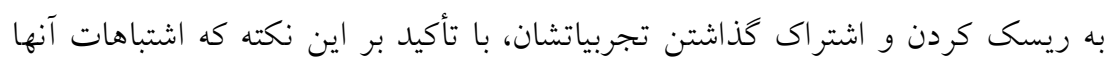

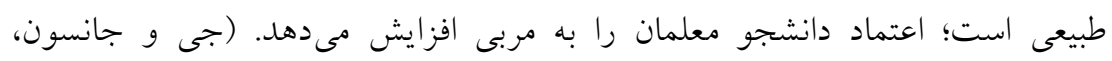

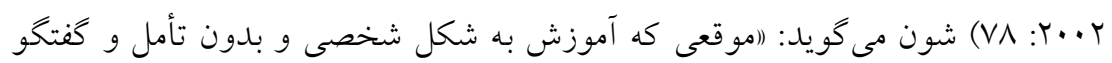

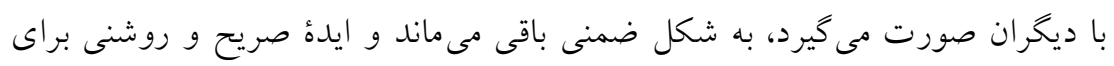

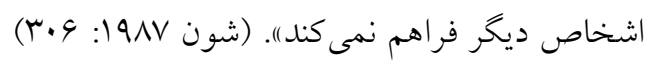

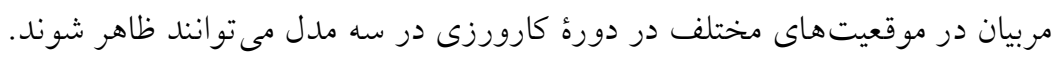

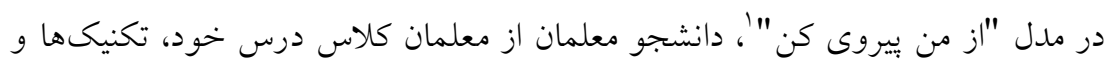

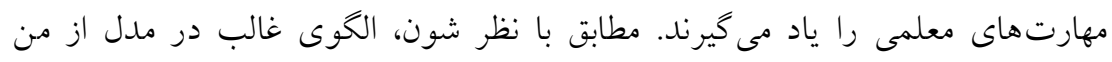

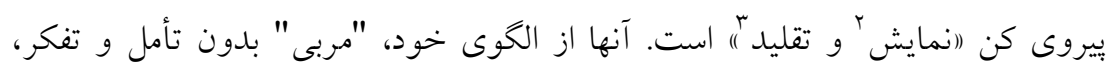

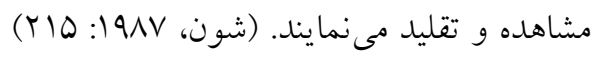

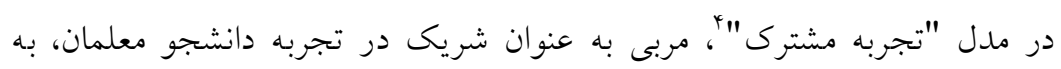

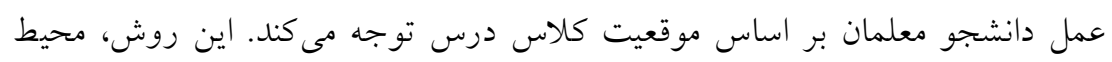

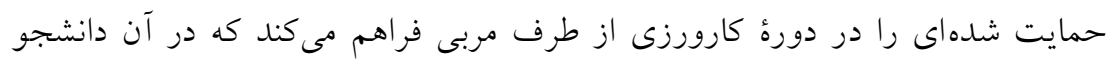

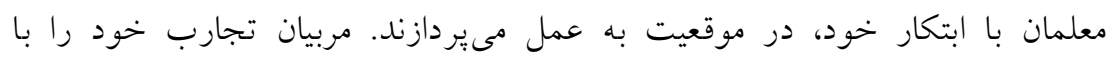

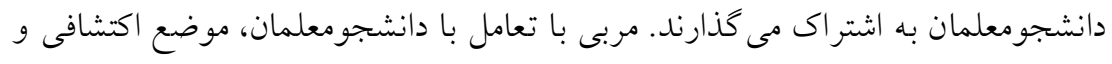

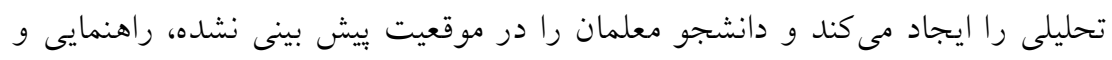

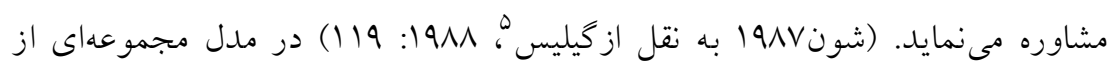

1 -follow me model

2 -demonstration

3 -imitation

4 -joint exprementation

5 - Gillis 
بازانديشىها'، دانشجو و مربى تمايل به اشتراى كذارى تجارب با يكديخر دارند. در

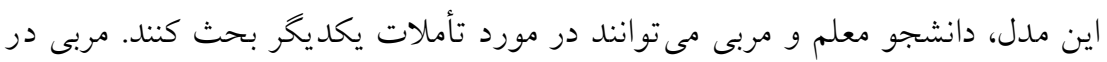

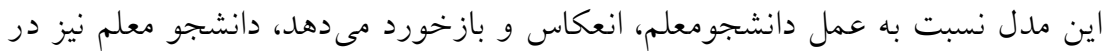
مورد عملهاى مربى بازانديشى مى كند. شون(19NV) مى گويد: (ادر اين روش مربى و و

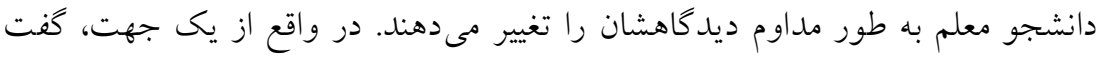

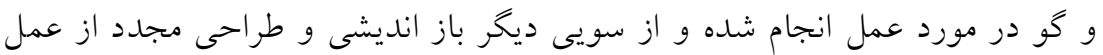

$$
\text { صورت مى گيرد). }
$$

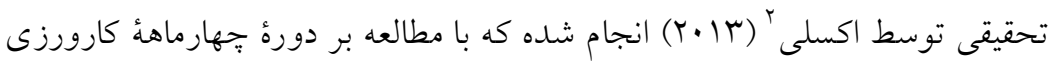
به اين نتايج دست يافت كه ايجاد اجتماعات حرفهاى براى تبادل اطلاعات، تأمل و و

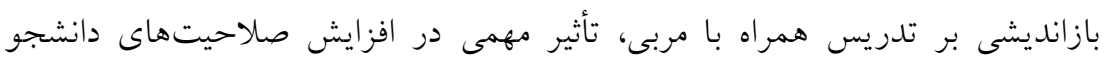

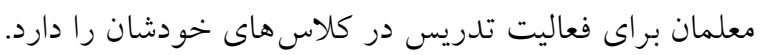

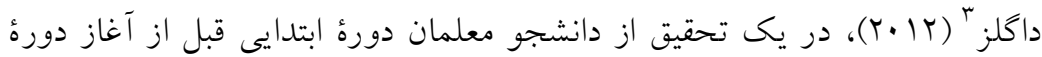

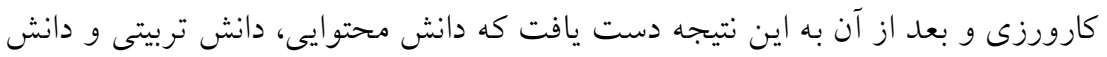

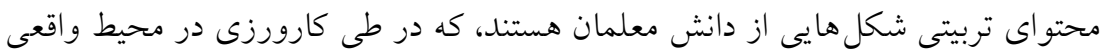

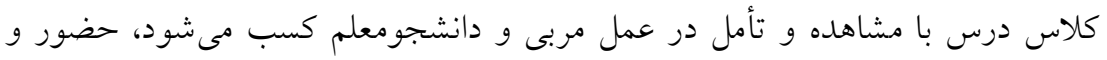
تدريس دروس قبل از شروع شغل معلمى، با ايجاد اين دانشها در معلمان در موقعيتهاى كلاس درس موثر است.

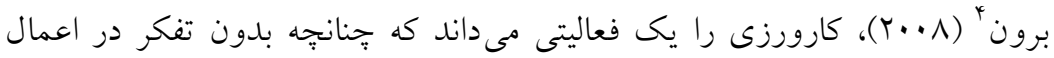

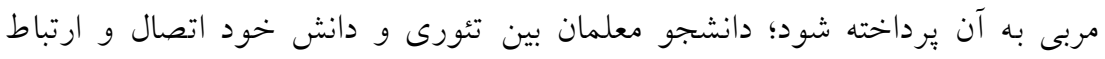

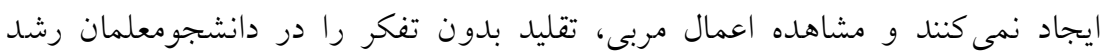

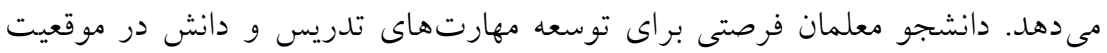

1 -hall of mirrors

2 -Xiuli

${ }^{3}$-Douglas

${ }^{4}$-Brown 
كلاس درس، مديريت آن و آشنايى با فرهنخهاى متفاوت از دانش آموزان به دست نمى آورند.

مكلين' (Y........ كارورزى فكورانه را به عنوان راهى براى انتقاد، تجزيه و تحليل

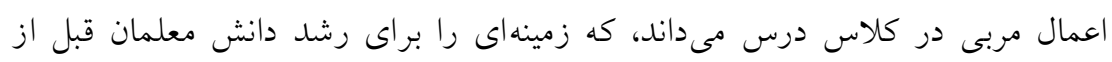
ورود به كلاس هاى و اقعى فراهم مى كند.

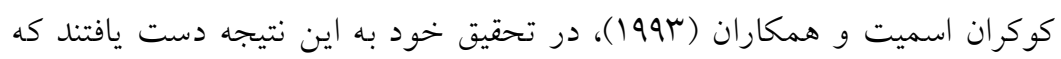

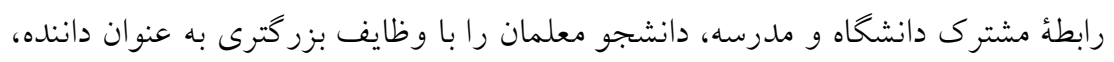

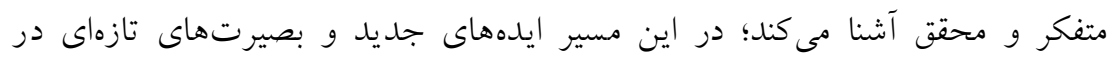
ضمن فعاليت در محيطهاى واقعى كلاس درس با مربيان ايجاد مى فودد.

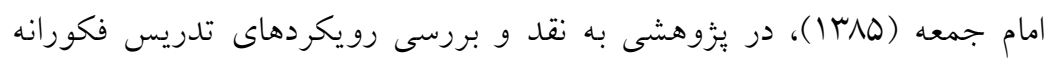

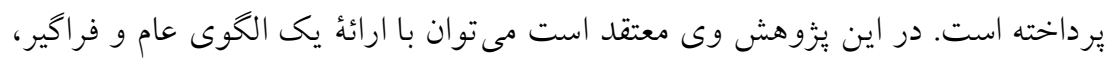

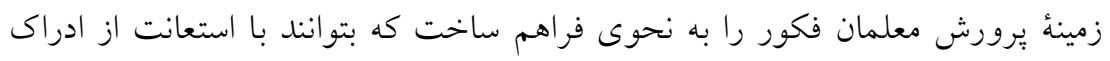

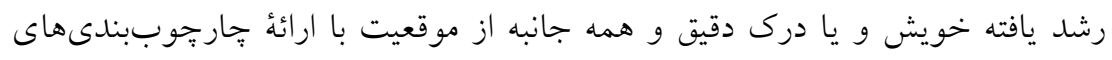

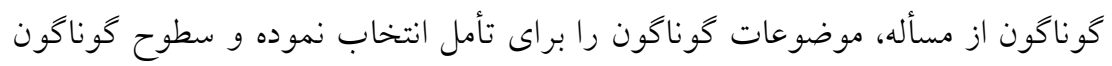
تدريس فكورانه را طى نمايند.

بنابراين بزّوهشها نشان مى دهد كه مربيان مجرب و و ارزياب در مكانهاى مدرسه،

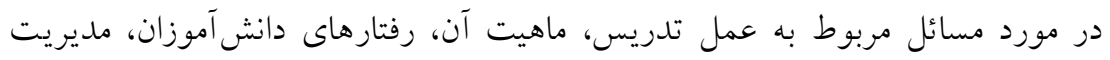

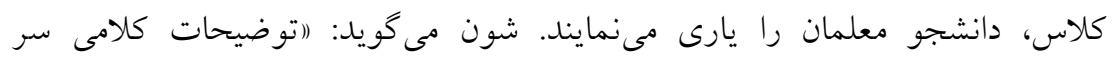

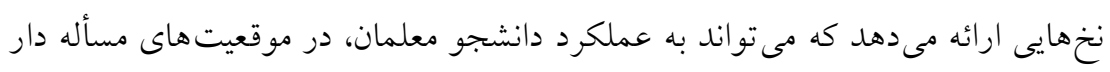

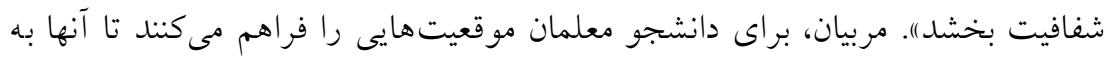

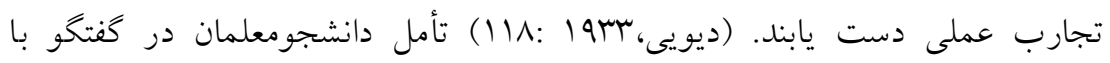

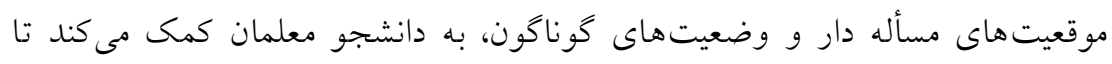

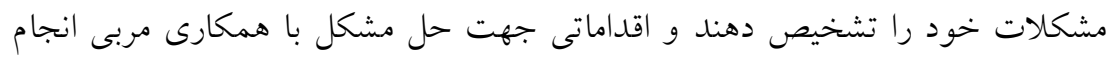

${ }^{1}$-MacLean 


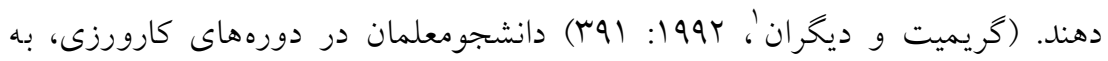

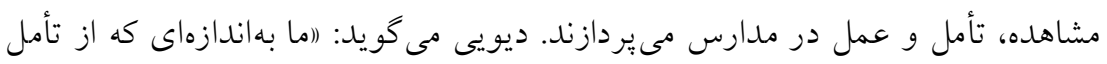

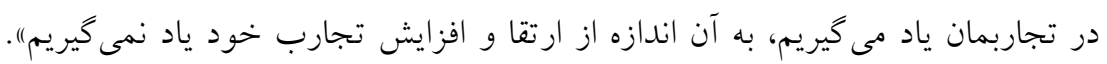

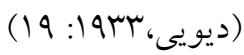
با اين حال بايد دانست كه همه موقعيت ها در كارورزى، زمينهاى را براى تقويت

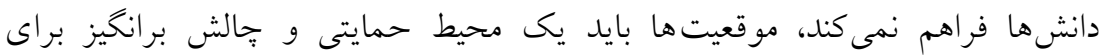

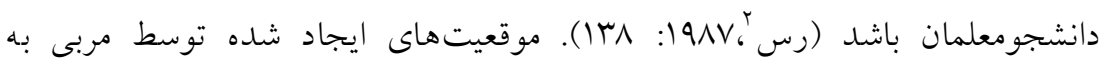

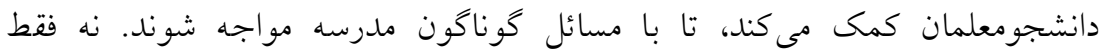
موقعيتها بايد حمايت شود، بلكه بايد مسائل و رخدادهايى براى دانشجو معلمان

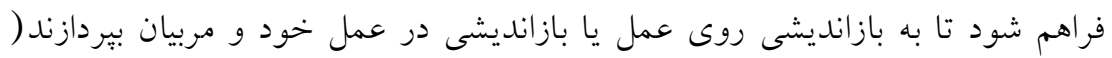

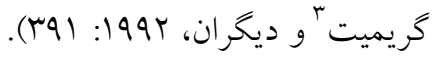

آموزش بدون حمايت مربيان در محيط مدرسه، تجارب معندرابه مدارى را براى

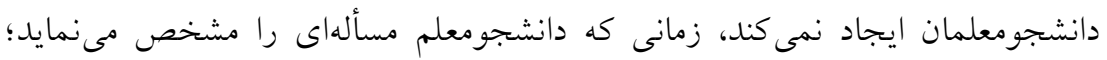

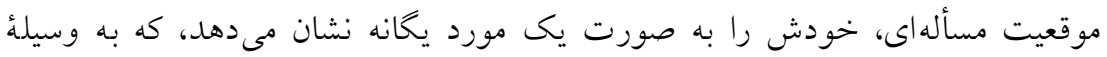

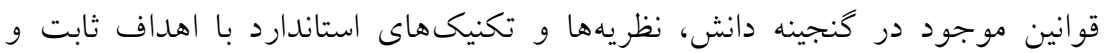

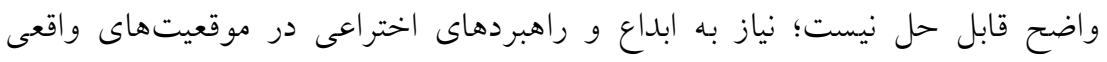

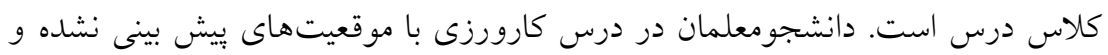

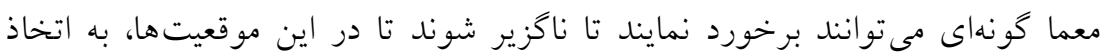

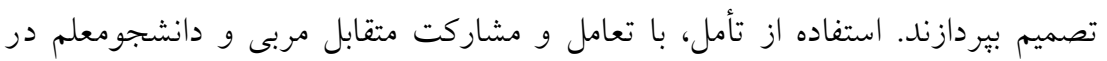

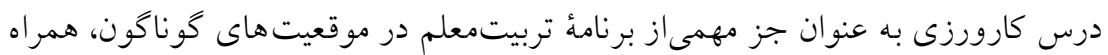

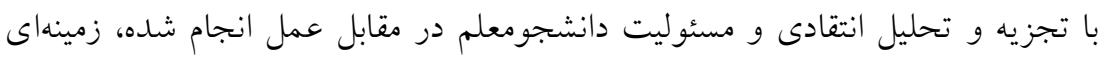

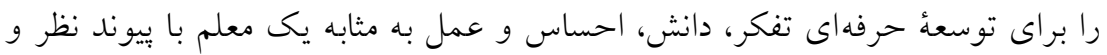

\footnotetext{
1 - Grimmet \& et al

2 -Ross

3 -Grimmet
} 
عمل در موقعيتهاى كوناكون كلاس درس فراهم مىنمايد؛ مربى به عنوان يكى از

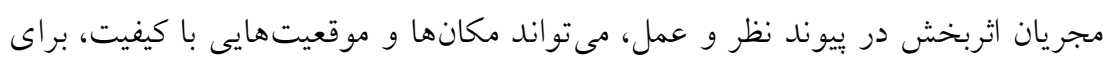

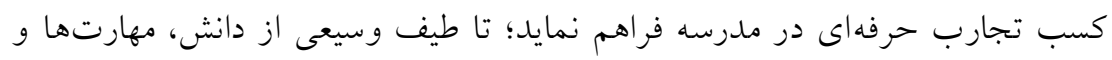

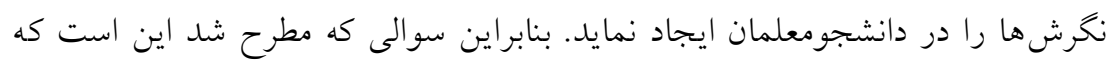

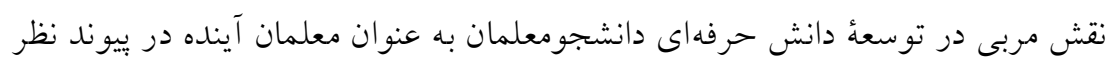

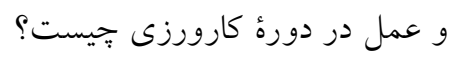

\section{روش ئزوهش}

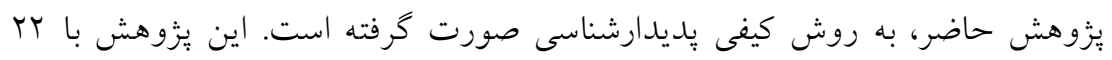

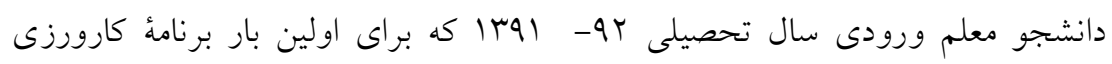

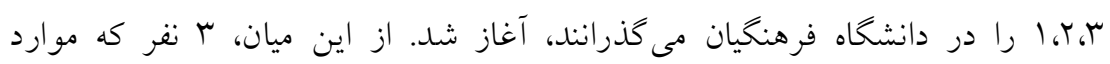

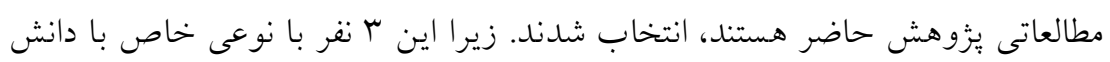

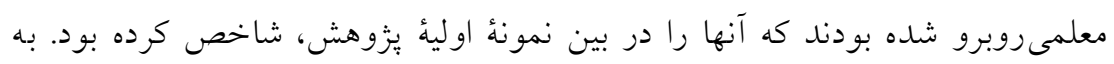

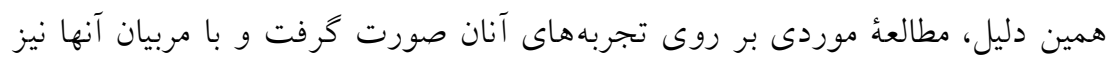

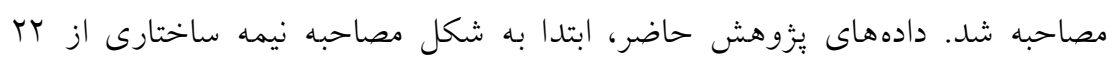

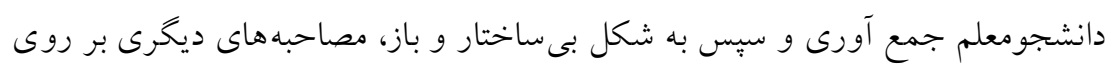

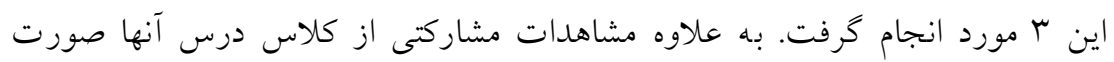

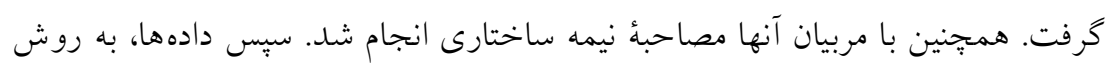

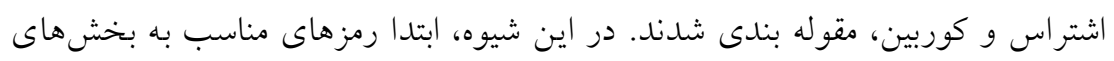

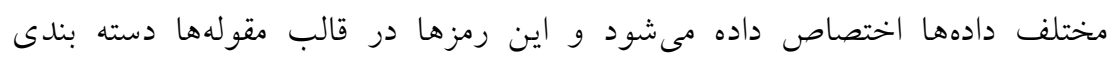

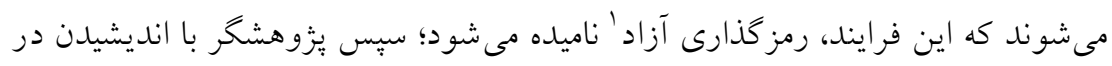

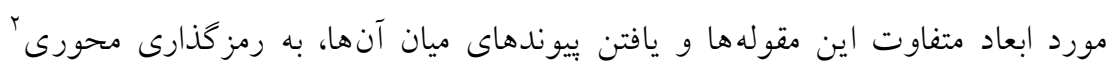

1 -open coding

2 -axial coding 
اقدام مى كند. لازم به ذكر است كه در جريان اين رمز كذارىها، يُزوهشكر با استفاده از

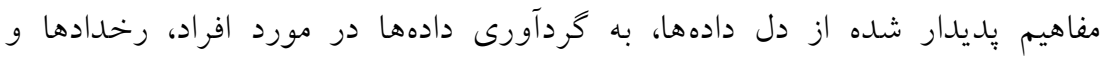
موقعيت هاى مختلفى مى يردازد كه تصوير غنى ترى از مفاهيم و مقو له هاى حاصل، فراهم

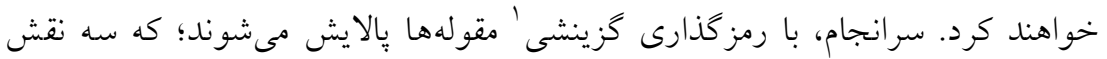
براى مربى ترسيم گرديد كه در ادامه توصيف و تحليل مىشود.

\section{يافته ها}

يافته هاى شركت كنندة شمارهُ ا: مربى به عنوان بيرو و مقلد (از من بيروى كن)

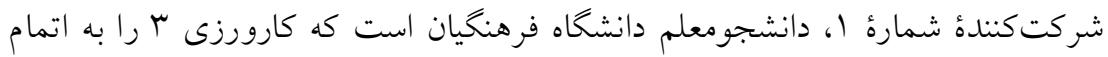

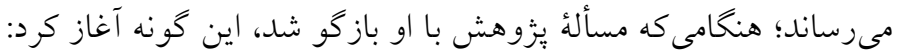

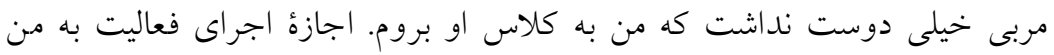
نمى داد و مى كفت: (اتدريس شما خيلى وقت مى بره و بر اي كلاس هاى درس با جمعيت

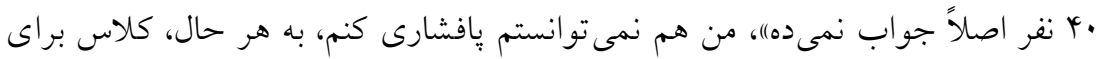

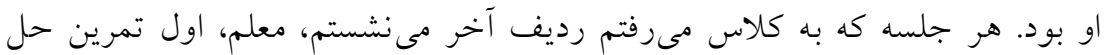

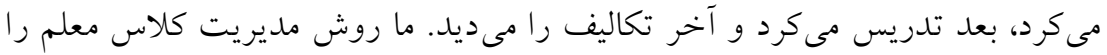

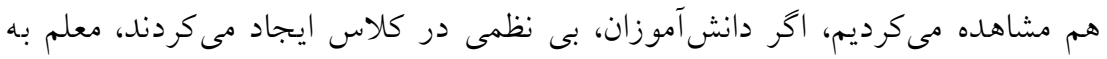

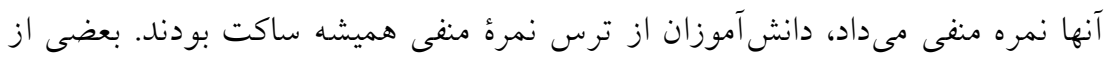

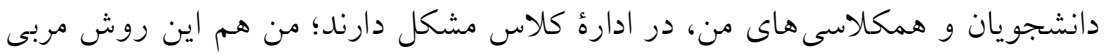

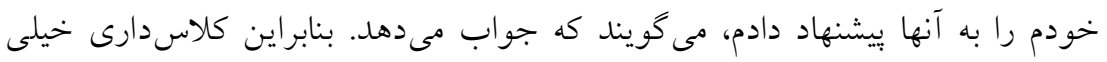

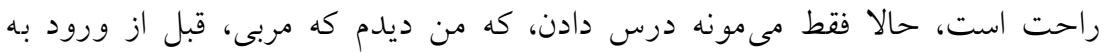
كلاس، متن كتاب را مطالعه كلى مى كنه، من مىتوانم بيشترين وقت را روسى روى مطالعه منه كتاب در سالهاى اول تدريس بخذارم.

\footnotetext{
${ }^{1}$-selective coding
} 
مربى به بجنها ها درس مىداد، بعد از آنها مى يرسيد، تا متوجه شود كه آنها ياد كرفتند

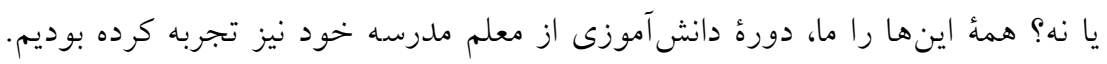

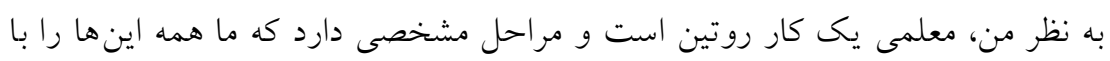

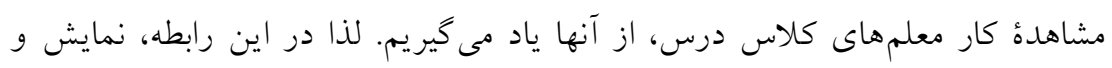
تقليد از مربى در حال روى دادن است. در تعامل با مربى، از ايشان خواسته شد تا شرح اين ارتباط بازگو گردد و ابتدا يك تبيين

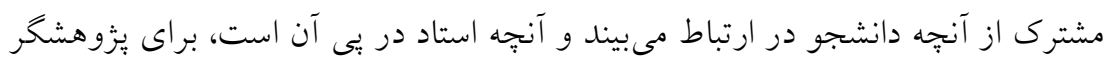
نمايان شود.

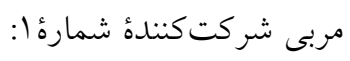

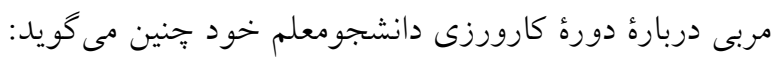

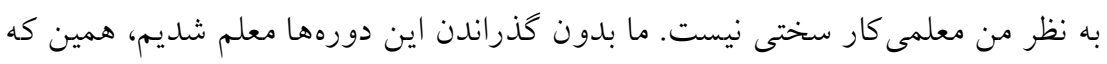

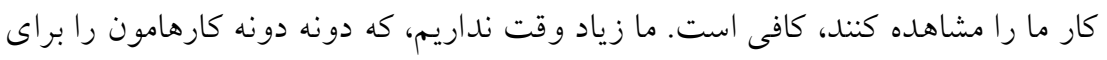

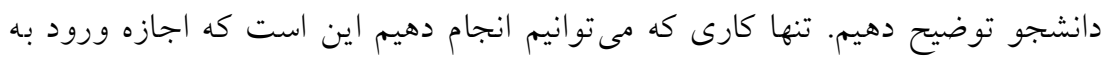

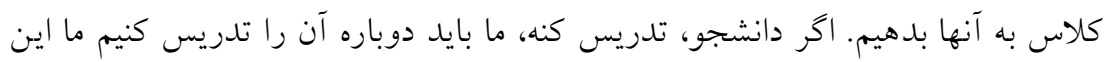

$$
\text { قدر وقت نداريم. }
$$

دانشجويان بايد اين تجربه را به كلاسهاى درس خودشان موكول كنند؛ رفتار و

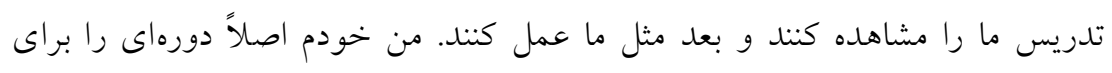

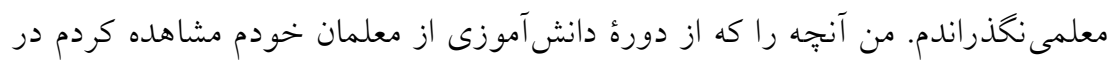
كلاس اجرا كردم، الان به راحتى كلاس را اداره مى كنم، درس مئ دهمب...

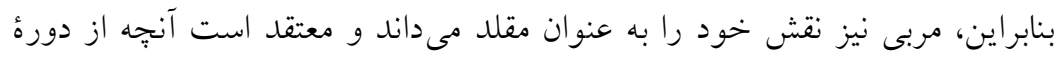

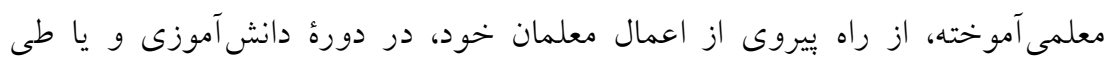

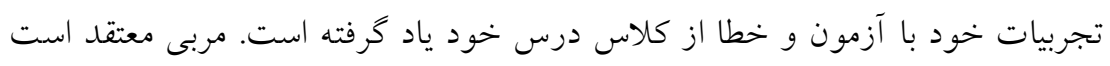

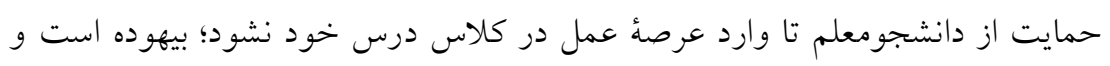


دو فصلنامة نظريه و عمل در برنامة درسى، شماره V، سال جهارم، بهار و تابستان 9011

نياز به هيج تعامل و كفتخويى ميان دانشجو و مربى نيست. او معلمى را كارى روتين و

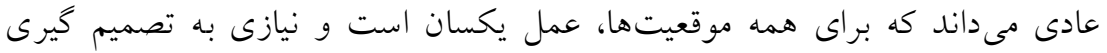
معلم در موقعيتهاى گوناكون ندارد.

\section{يافته هاى شركت كنتدة شمارة ץ: مربى به عنوان شريك در تجارب}

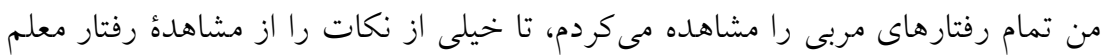

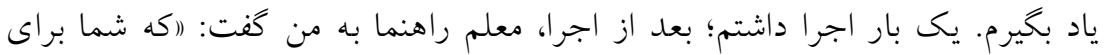

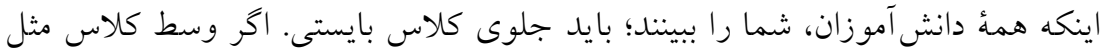

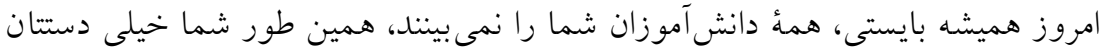
را حركت مى دهيد، ظاهر و حركات دست و حتى لحن و جهره با محتواى تدريس بايد ارتباط داشته باشد، بايد اجراى خودت را زمان بندى كنى، زياد به قسمت مثال زدن

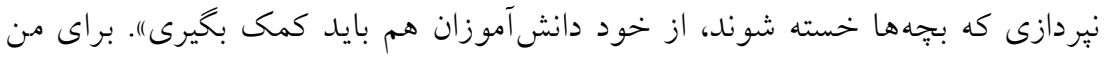

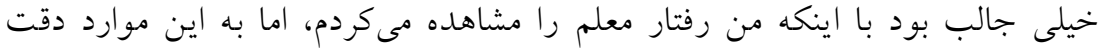
زيادى نداشتم؛ راهنمايى مربى به من خيلى كمك كرد.

دانشجومعلم از ارتباط ميان مربى بسيار خرسند بود، جرا كه معتقد بود با با اينكه

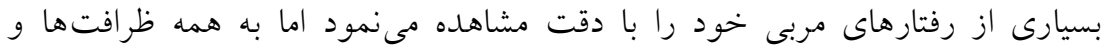

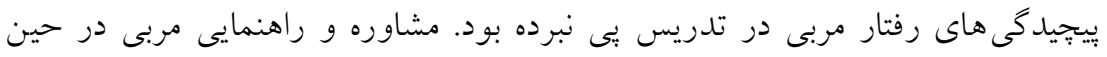

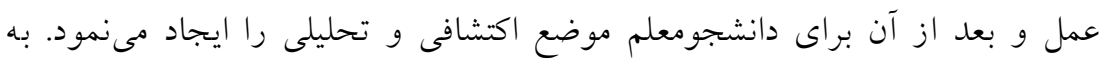
طورى كه دانشجومعلم از ارتباط مربى با خود مى كويلد:

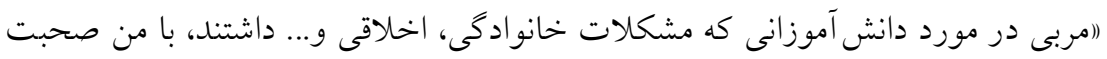

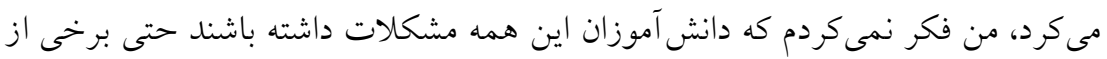

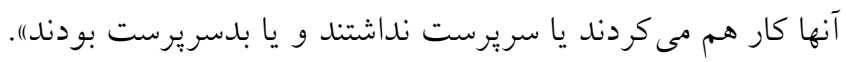

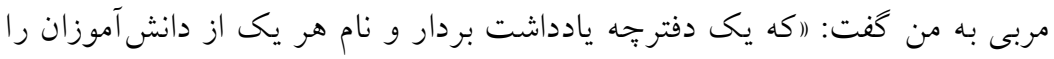

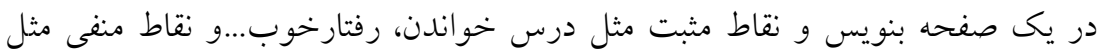


درس نخواندن، بى نظمى را براى هر دانشآموز ثبت كن، ما مىتوانيم راجع به اين

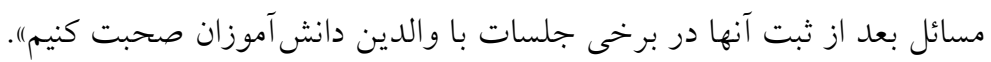

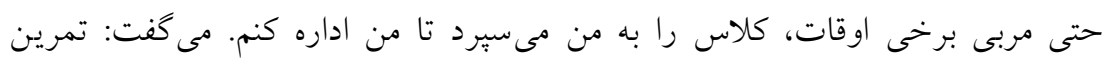

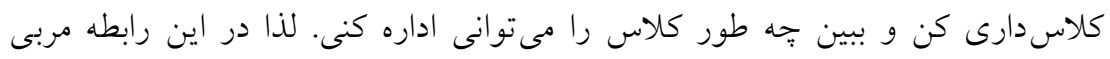

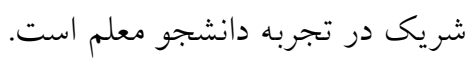

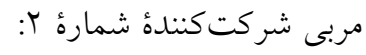

$$
\begin{aligned}
& \text { از مربى نيز خواسته شد تا شرح اين ارتباط باز كو گردد: }
\end{aligned}
$$

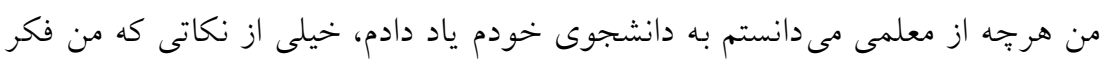

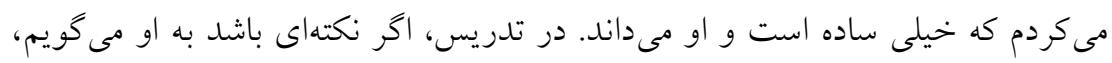

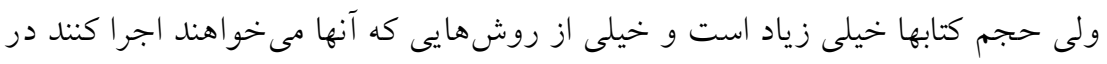

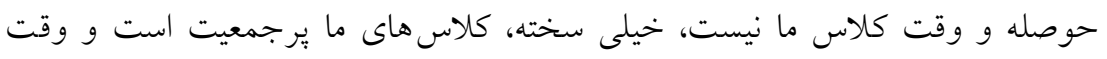

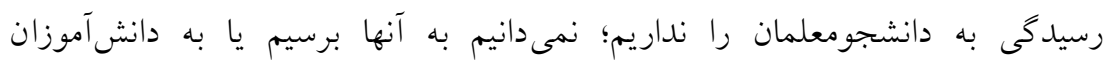

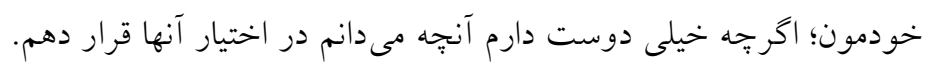

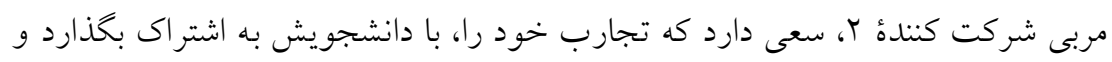

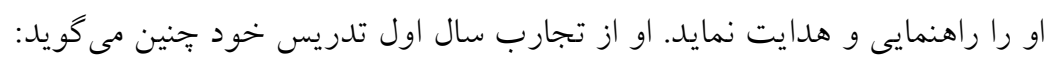

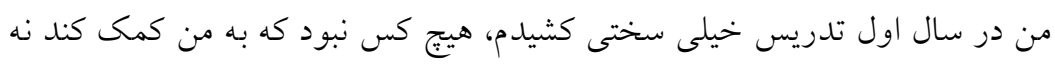

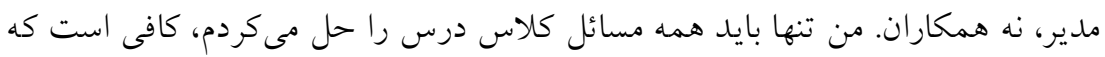

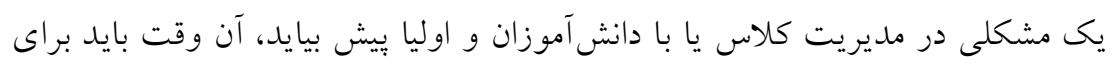

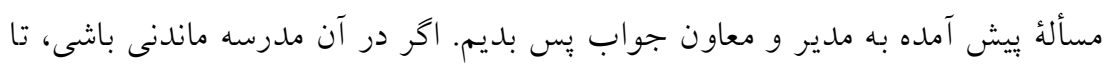

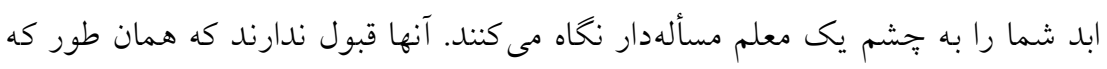

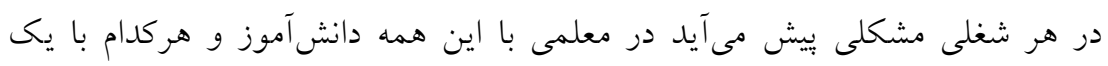

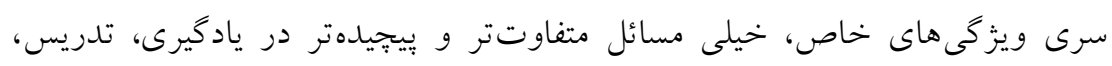


دو فصلنامة نظريه و عمل در برنامئ درسى، شماره V، سال جهارم، بهار و تابستان 9011

مديريت و از اين نوع برايشان بيش مى آيد كه بايد از اولياء و اعضاء مدرسه كمك كرفت، نه آن را مخفى كرد. مربى مشاركت كنندة rا، معتقد است كه كمك و مشاورة اعضاء مدرسه در موقعيتهاى كلاس درس باعث حل مسائل و مشكالات دانشجومعلمان در مورد مديريت، روش تدريس، روش ارزشيابى، ويزگ گهاى اخلاقى معلم... مى گردد. بنابراين، موضع يك مشاور و شريك در تجارب دانشجومعلم را ايفا مىنمايد.

يافته هاى شركت كنتدهُ شمارةٌ ب: مدل مجموعهاى از باز انديشىها من همهُ رفتارهاى مربى را مشاهده مى كردم، مربى به من كفت: يك دفتر جهه يادداشت با خودت سر كلاس ببر و هر جهه در رفتارهاى من توجهات را جلب مىكرد، را بنويس. در اين مدل با اينكه شركت كنندة شمارهُ ب به مشاهدة اعمال مربى مى يردازد، اما مربى از او مى خواهد كه بازخوردهايى از اعمال او، با نوشتن مطالبى از اعمال او دربارهُ مديريت كلاس، روش تدريس، ارزشيابى، ارتباط با دانشآموزان، اخلاق و... از ضعفها و قوتها، زمينهاى را بر اي بازانديشى بر عمل و رفتار او فراهم نمايد تا دانشجومعلم خود با تفكر و بازانديشى به همراه مربى به نتايج سودمندى دست يابد. مربى در مقايسه با معلمان دورهُ تحصيلم، خيلى متفاوت بود. روش او مشاركتى بود، دانشآموزان را كروه بندى مىكرد. مربى مى گفت: مشاركت نوعى آزادى به دانشآموزان مىدهد. دانشآموزان ساعت كلاس او را دوست داشتند، با اين تفاوت كه من از ساعت اين درس در دوره دانشآموزى بيزار بودم. در اجراى فعاليتهايم، وقت و بى وقت با او تماس مى گرفتم. حتى اگر وقت بود، من و مربى با هم آزمون طراحى مى كرديم، مربى به تمام حالات دانشآموزان توجه مى كرد، هم ضعف ها و هم نقاط قوت آنها، كلاسش را به خوبى اداره مىكرد، جنانجه بىنظمى يا مسألهاى در كلاس رخ مى داد، اكر لازم بود؛؛ سر كلاس و گرنه بالافاصله بعد 
از اتمام كلاس با دانش آموزان صحبت مىكرد و كاهى با اولياى دانش آموزان نيز كفتخو مى كرد.

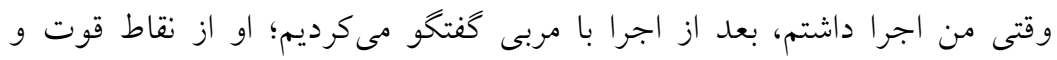

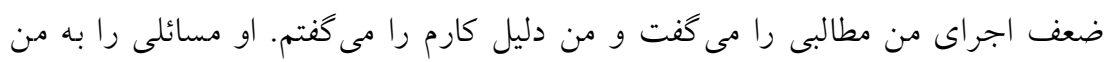

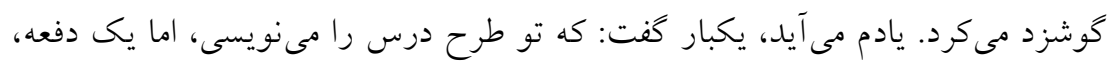

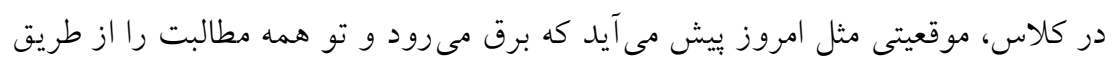

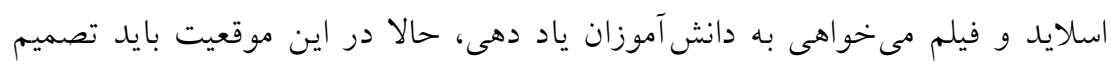

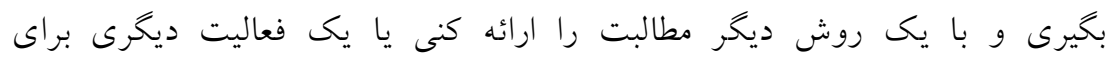

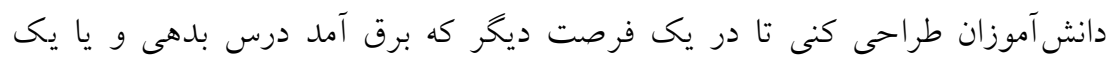

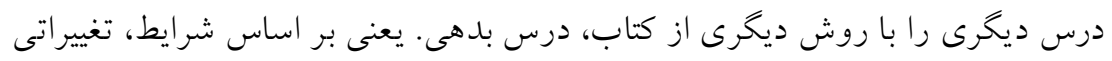

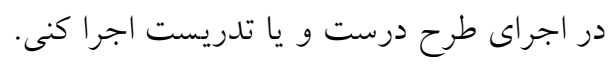

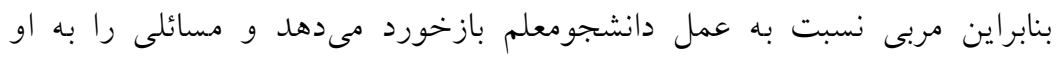

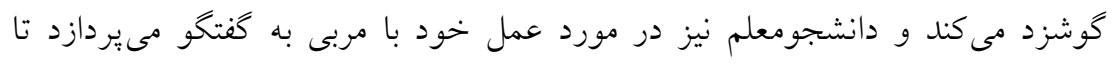

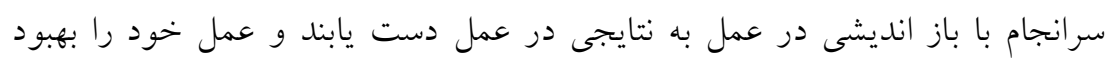
دهند.

مربى به من كفت: (اكاش تا بايان سال، شما در كلاس من بوديد تا ما اطلاعات و

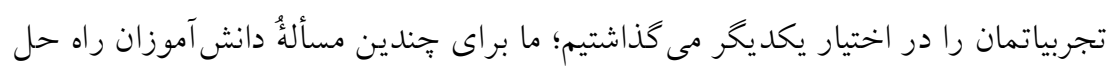

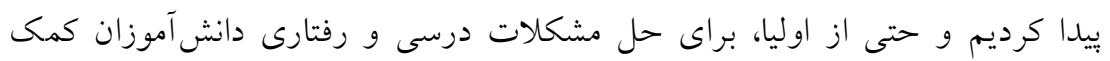

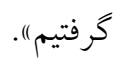

مربى شركت كنتدهُ شمارهُ با:

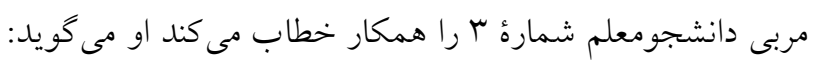

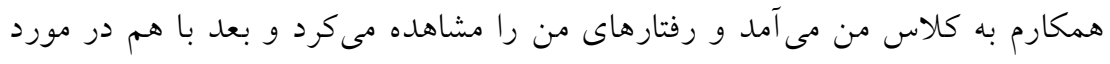

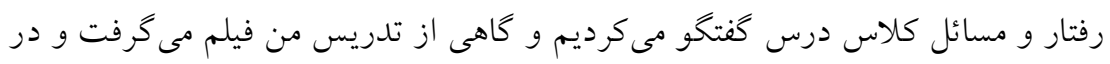




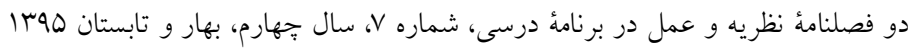

مورد آن در زنخ تفريح صحبت مى كرديم. ما خيلى از اطلاعات و تجاربمون را با هم

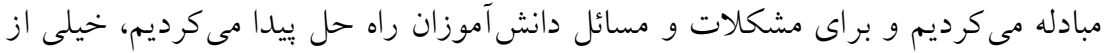

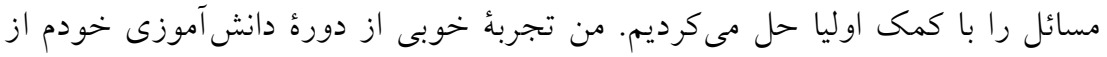

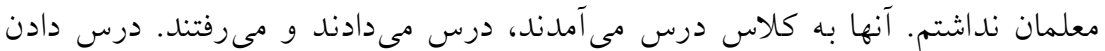

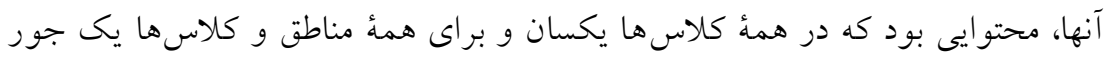

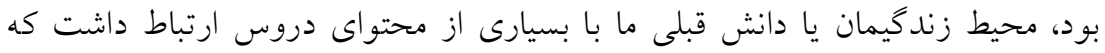

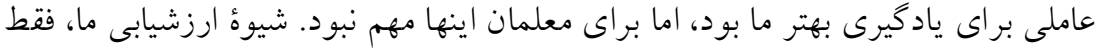

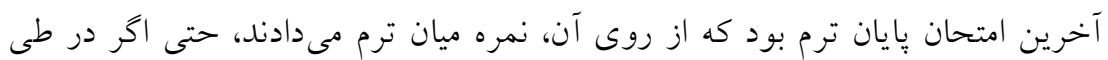
سال درس مى خو انديم و يكى اتفاقى شب امتحان مى افتاد؛ نمرة بر كه ملاكى بوده.

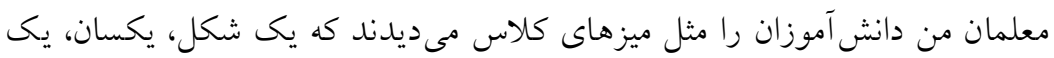

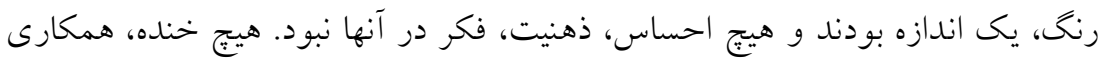
و مشاركتى در كلاسهاى ما نبود و همه انتظار تمام شدن كلاس درس را مى كشيديم.

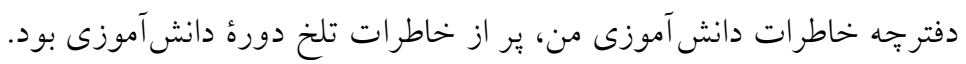

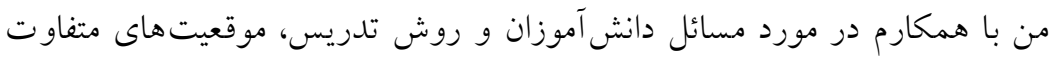

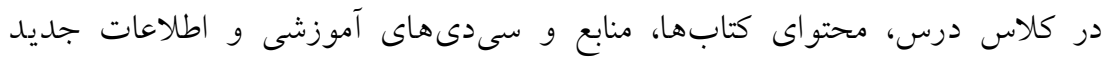

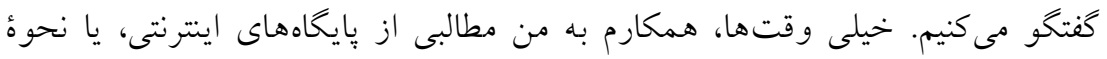

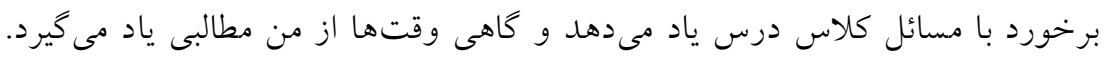

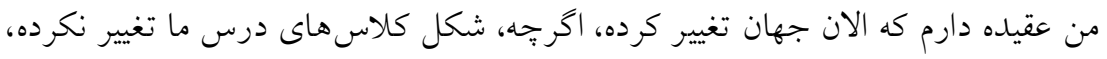
اما ما مىتوانيم روش، كلمات، برخوردها، محتواى مطالب را تغيير دهيم. معلم بايد

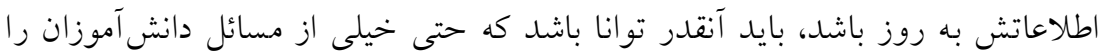
حل نمايد.

معلمى شغل خيلى سختى است، با هنرمندى در موقعيتهاى متفاوت همراه است،

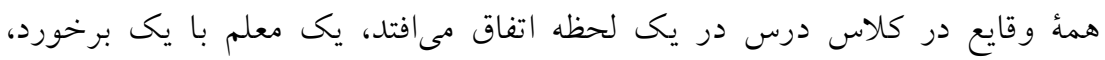

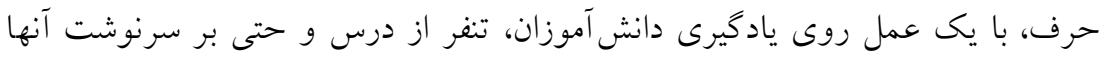


دخيل مىشود، اين مسائل را حتى در روايتهاى معلمان از دورةٌ دانش آموزىشان و

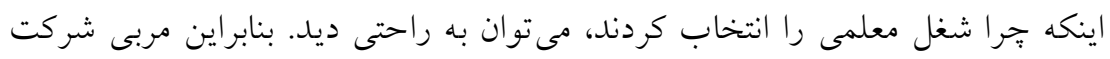

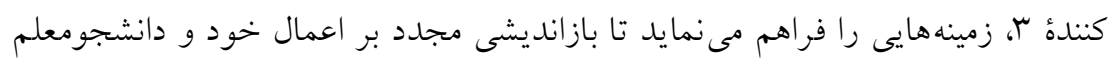

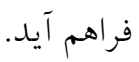

\section{بحث و نتيجه گيرى}

يُوهش حاضر به دنبال بررسى روش مربى در شكل گيرى دانش دانشجو معلمان در

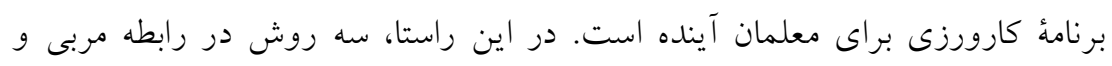
دانشجومعلم شناسايى شد: همان طوركه مطالب شركت كنندة شمارهُ 1 و مربى او، كوياى اين امر است كه

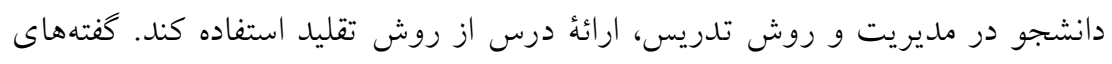

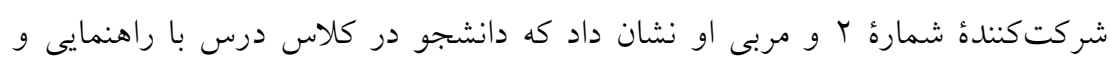

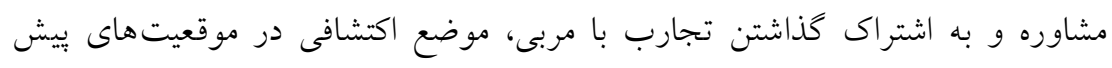

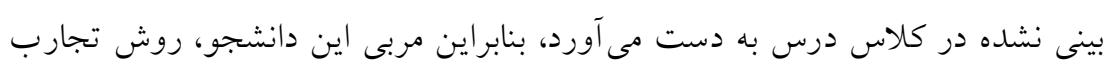

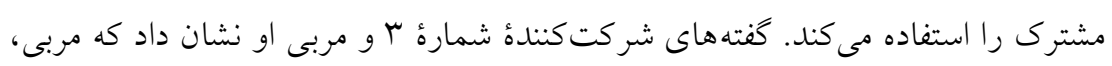

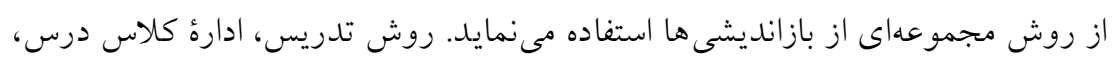

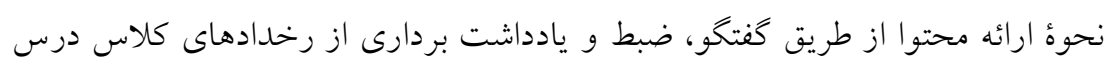

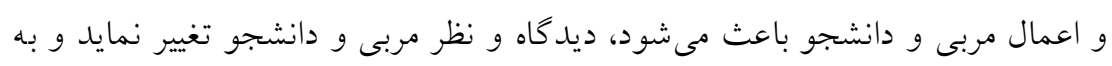
باز انديشى و طراحى مجدد از عمل بيردازند.

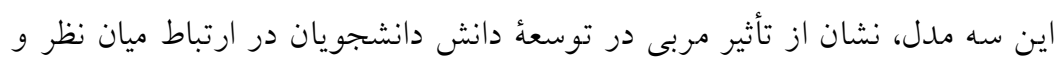

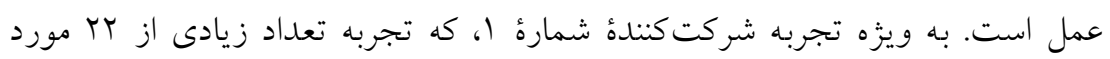

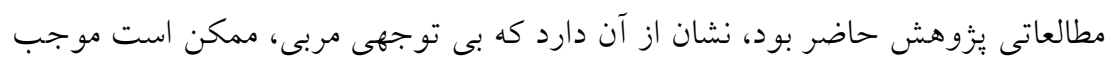

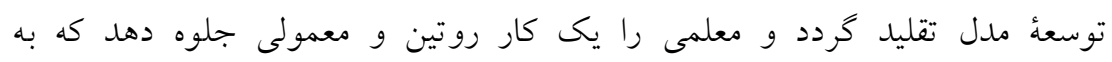

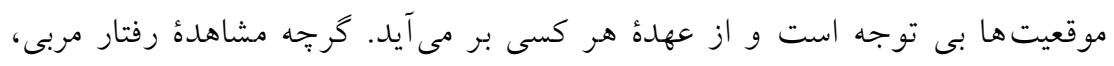


دو فصلنامه نظريه و عمل در برنامهُ درسى، شماره V، سال جهارم، بهار و تابستان ه9r|

همان طور كه در شركت كنندهُ شمارة Y و r نيز به آن توجه شده، جزئى از برنامهُ كارورزى است؛ اما تقليد، از مشاهدات اعمال يكسان و روتين را در كلاس درس رواج مى دهد. شركت كنندهُ شمارة با، از مشاهدات خود تقليد نمى نمايل، بلكه مربى زمينهاى را براى تفكر در مشاهدات و عمل در كالس درس فراهم مىنمايد. اما در روش مجموعهاى از باز انديشىها، شركت كنندهُ شمارهُ با، هر دو طرف دانشجو و مربى در مورد تأملات يكديخر بحث مى كنند و نسبت به عملهاى يكديخر انعكاس و بازخورد مى دهند. ايدهها، نيازها، تجارب و موقعيتهاى كلاس درس را حلاجى و بررسى مىنمايد و ديدكاههاى يكديخر را بررسى نموده و حتى دوباره شكل مىدهند. مدل سوم، عملاً بر تجرخهُ ياد گيرى مشاركتى در مراحل بيدا كردن مسأله، طراحى، عمل، بازانديشى و ياد گيرى استوار مى گردد. دانشجومعلمان فرصت مى يابند تا توانايىهاى حرفهاى خود را ارتقا و بهبود بخشند و در انجام وظايف حرفهاى خود، آنها را توانمندتر سازند؛ در خصوص اين مهم مىتوان بيشنهاد كرد كه مربيان، نسبت به اين نقش مهم آكاه شوند تا به هنخام كار با دانشجومعلم، به توسعهُ دانش و مهارت معلمى بيانديشند. مىتوان انتظار داشت كه تغيير در باورهاى مربى، تأثير بر توسعهُ دانش دانشجومعلم دارد. آنجهه در مورد نتايج يُزوهش حاضر لازم به ذكر است، اين است كه در ميان روشهاى مطرح در اين بزوهش، تقليد، شريك در تجارب، مجموعهاى از بازانديشى ها و بازخوردها، اخر جهه هرسه شركت كننده از طريق مشاهده نيز، در حال توسعهُ دانش معلمى هستند؛ تفاوت در آن است كه شركت كنندهُ شمارهُ ا، در برنامه از من بييروى كن قرار دارد و تنها به تقليد از مربى مى بردازد. شركت كنندهُ شمارهٔ ז، در مدل شريك در تجارب قرار دارد؛ كه مربى، موقعيتهايى را براى عمل و اجراى فعاليتها فراهم مى كند تا دانشجومعلم را در موقعيتهاى گوناگون هدايت نمايد، و و شركت كننده شماره ما، به بازانديشى و طراحى مجدد فعاليتهاى خود و مربى مى بردازد. بنابراين بيشنهاد مقالهُ حاضر، توجه به روش مجموعهاى از بازانديشى ها در تربيت دانشجومعلمان در برنامهُ كارورزى در بييوند نظر و عمل مورد توجه است؛ به 
طورى كه مربى با اين روش مىتواند عهلده دار توسعلة ابعاد دانش و مهارت

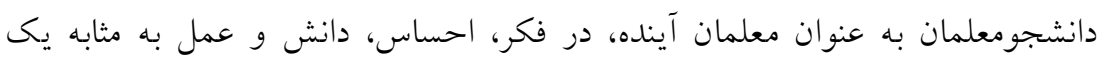

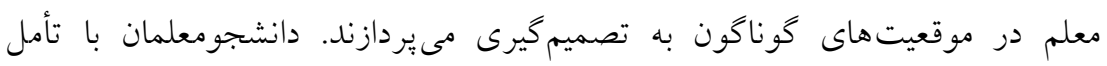

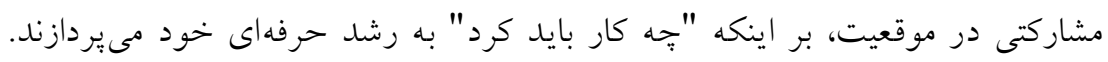

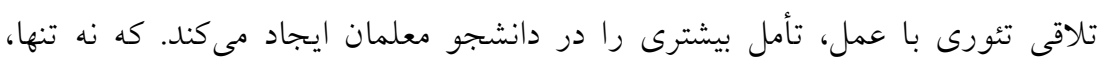

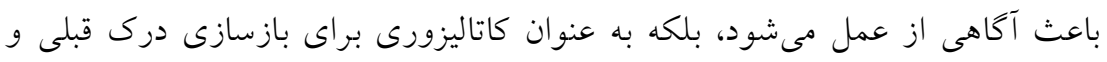

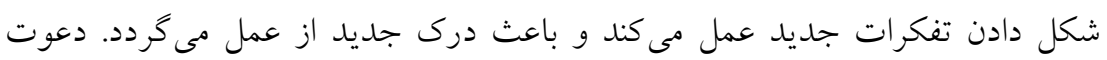

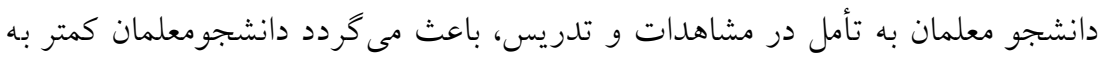

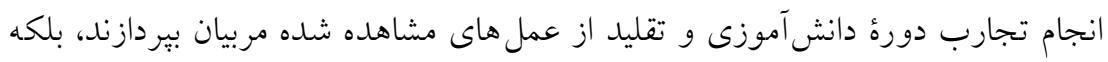
به تلفيق و تغيير شكل دادن يادكيرىهاى خود مى يردازند. بنابراين مربى بايد بتواند

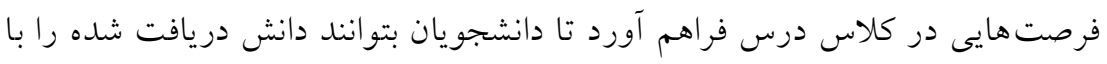

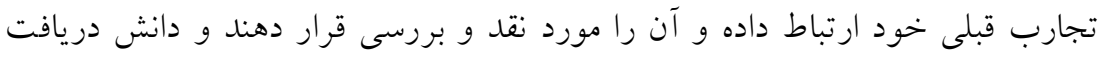

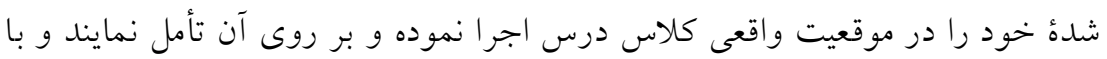

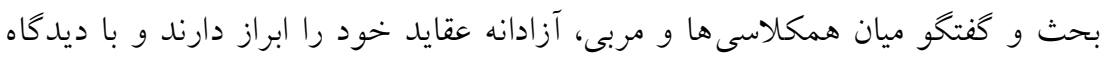

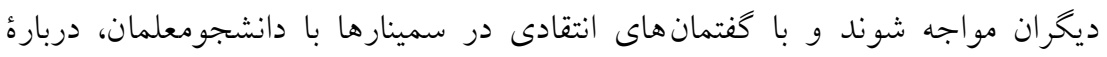

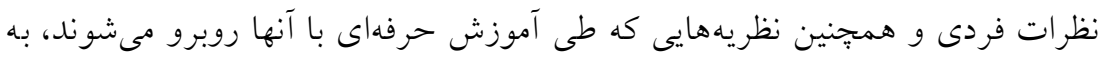

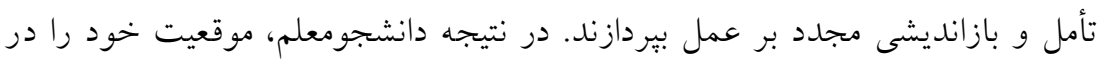

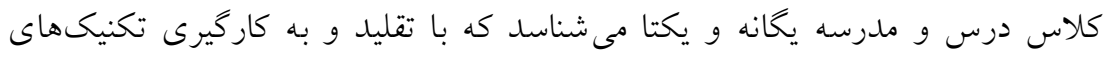

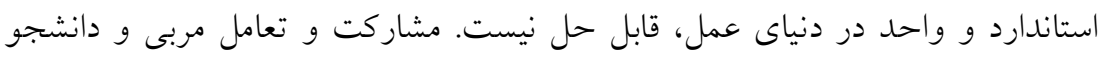

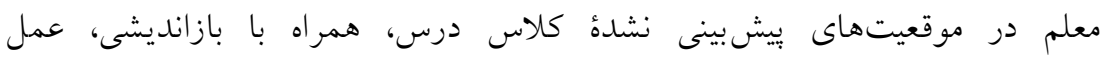

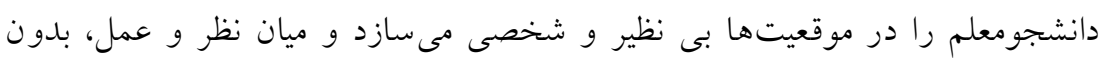
تأكيد بر الكوى واحد، بييوند ايجاد مى نمايد. 


$$
\text { - }
$$

-Braun, J. A. \& Crumpler, T. P. (2004). The social memoir: An analysis of developing reflective ability in a pre-service methods course. Teaching and Teacher Education, 20 (1), 59-75.

-Brown, N. (2008). Assessment in the Professional area Context. Center for the Advancement of Learning and Teaching. University of Tasmania.

-Burnaford, G., \& Hobson, D. (1999). Beginning with the group: Collaboration as the cornerstone of graduate teacher education. Action in Teacher Education, 17(3), 67-75.

-Cochran-Smith, M. \& Lytle, S. (1993). Inside/Outside teacher research and knowledge. New York: Teachers College Press.

-Dewey, J. (1933). How we think: A restatement of the relation of reflective thinking to the educative process. Boston: D.C. Heath.

-Douglas Adler James ( 2012), from campuz to class room: a study of elementry Tteacher canadeans' pedagogical content knowlege, THE UNIVERSITY OF BRITISH COLUMBIA, doctor of philosophy.

-Feiman-Nemser, S. (2008). Teacher learning: How do teachers learn to teach? In Cochran- Smith, M., Feiman-Nemser, S., McIntyre, D.J.,Demers, K.E. (Eds.), Handbook of research on teacher Education: Enduring questions in changing context (3rd ed. , p.( 697705). New York: Routledge.

-Feiman Nemser,S., McIntyre, D.J.,Demers, K.E(2010).(Eds.),Handbook of research on teacher Education: 
تجارب دانشجومعلمان از نقش مربى ...

Enduring questions in changing context (3rd ed. , p.( 697- 705). New York: Routledge.

-Farrell, T. (2008). Reflective practice in the professional development of teachers of adult English language learners. Retrieved January 8, 2009 , from

http://www.cal.org/caelanetwork/pd resources/reflectivepractice.html -Fuller, F. (1987). Concerns of teachers: A developmental conceptualization. American Educational Research Journal, 6, 207 226.

-George, J., Worrell, P., Rampersad, J., and Rampaul, B. ( 2000). Becoming a primary school teacher in Trindad and Tobago (Part 2,Teaching practice experience of Trainees).

-Gillis, G. (1988). Schon's Reflective Practitioner: A Model for Teacher? In P.P. Grimmett and G.L. Erickson (Eds.), Reflection in Teacher Education (pp.47-53). New York: Teachers College .

-Griffiths, V. (2000). The reflective dimension in teacher education. Internation Journal of Educational Research, 33, 539-555.

-Grimmet, P.P., \& McKinnon, A.M. (1992). Craft knowledge and the education of teachers. Review of Research inEducation, 18, 385-456.

-Hammerness, K., Darling-Hammond, L., Bransford, J., Berliner, D., Cochran-Smith, M., McDonald, M, Zeichner, K. (2005). How teachers learn and develop. In L. Darling--Hammond \& J. Bransford (Eds.), Preparing teachers for a changing world: What teachers should learn and be able to do. San Francisco, CA: Jossey-Bass.

Zeichner, K. (2005). How teachers learn and develop. In L. Darling-Hammond \& J. Bransford (Eds.), Preparing teachers for a changing world: What teachers should learn and be able to do. San Francisco, CA: Jossey-Bass.

-Jay, J. K. \& Johnson, K. L (2002). Capturing complexity: a typology of reflective practice for teacher education. Teaching and Teacher Education 18,73 - 85 .

-Killon, J. P. \& Todnem, G. R. (1991). A process of personal theory building.Educational Leadership, 48 (6), 14-16.

-Korthagen, F. A. J. (1993). Two modes of reflection. Teaching and Teacher Education, 9 (3), 317-335.

-Lortie D. (1975). Schoolteacher. Chicago: University of Chicago Press. 
-MacLean, M. (2004). Recommendations for teacher educators and professionaldevelopers. In M. Mohr, C. Rogers, B. Stanford, M. A. Nocerino, M. MacLean, \& S.Clawson (Eds.), Teacher research for better schools. 96-106. New York: TeachersCollege Press.

-Pennington, M. C. (1995). The teacher change cycle. TESOL Quarterly, 29 (4),705-731.

-Robinson, P., \& Darling-Hammond, L. (2005). Change for collaboration and collaboration for change: Transforming teaching through school-university partnerships. In L. Darling-Hammond (Ed.), Professional Development Schools: Schools for Developing a Profession(pp. 203-219). New York and London: Teachers' College, Columbia University.

-Ross, D. (1987). Action research for preservice teachers: A description of why and how. Peabody Journal of Education, 64 (3), 131-150.

-Schön, D. (1983). The Reflective Practitioner: How Professionals Think in Action,New York: Basic Books.

-Schon, D.A. (1987). Educating the Reflective Practitioner: Toward a New Design for Teaching and learning in the Professions, Sanfrancisco: Jossey bass.

-Schon, D.A. (1992).Extracts from the Theory of Inquiry Dewey's legacy to education, Curriculum Inquiry, 22(2):119-139.

-Smith, M. K. (2001) 'Donald Schön: learning, reflection and change', the encyclopedia of informal education. Retrieved on March 30, 2008,from: www.infed.org/thinkers/et-schon.htm

-Wenger, E. (1998). Communities of practice: Learning, meaning, and identity. NewYork: Cambridge University Press.

- Xiuli, M. (2013). Student Teachers' Professional Learning in Teaching Practicum, For the Degree of Doctor of Philosophy at the University of Hong Kong. 